\title{
Lessons learnt from the first EMEP intensive measurement periods
}

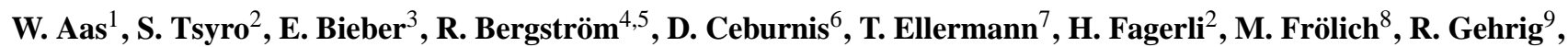 \\ U. Makkonen ${ }^{10}$, E. Nemitz ${ }^{11}$, R. Otjes ${ }^{12}$, N. Perez ${ }^{13}$, C. Perrino ${ }^{14}$, A. S. H. Prévôt ${ }^{15}$, J.-P. Putaud ${ }^{16}$, D. Simpson ${ }^{2,17}$, \\ G. Spindler ${ }^{18}$, M. Vana $^{19}$, and K. E. Yttri ${ }^{1}$ \\ ${ }^{1}$ Norwegian Institute for Air Research (NILU), Box 100, 2027 Kjeller, Norway \\ ${ }^{2}$ Norwegian Meteorological Institute, Oslo, Norway \\ ${ }^{3}$ Umweltbundesamt, Langen, Germany \\ ${ }^{4}$ Dept. Chemistry, Univ. of Gothenburg, Gothenburg, Sweden \\ ${ }^{5}$ Swedish Meteorological and Hydrological Institute, Norrköping, Sweden \\ ${ }^{6}$ School of Physics \& Center for Climate and Air Pollution Studies, Ryan Institute, National University of Ireland Galway, \\ Galway, Ireland \\ ${ }^{7}$ National Environmental Research Institute (NERI), Roskilde, Denmark \\ ${ }^{8}$ Umweltbundesamt, Vienna, Austria \\ ${ }^{9}$ Air Pollution, Environmental Technology EMPA, Dübendorf, Switzerland \\ ${ }^{10}$ Finnish Meteorological Institute (FMI), Helsinki, Finland \\ ${ }^{11}$ Centre for Ecology and Hydrology (CEH), Edinburgh, UK \\ ${ }^{12}$ Energy Centre of the Netherlands (ECN), Petten, The Netherlands \\ ${ }^{13}$ Institute of Environmental Assessment and Water Research (IDAEA-CSIC), Barcelona, Spain \\ ${ }^{14} \mathrm{CNR}$, The Institute for Atmospheric Pollution, Rome, Italy \\ ${ }^{15}$ Paul Scherrer Institut (PSI), Villigen, Switzerland \\ ${ }^{16}$ European Commission - DG Joint Research Centre, Ispra, Italy \\ ${ }^{17}$ Chalmers University of Technology, Gothenburg, Sweden \\ ${ }^{18}$ Leibniz Institute for Tropospheric Research (IfT) Leipzig, Germany \\ ${ }^{19}$ The Czech Hydrometeorological Institute (CHMI), Prague, Czech Republic
}

Correspondence to: W. Aas (waa@nilu.no)

Received: 9 January 2012 - Published in Atmos. Chem. Phys. Discuss.: 2 February 2012

Revised: 17 July 2012 - Accepted: 21 August 2012 - Published: 10 September 2012

\begin{abstract}
The first EMEP intensive measurement periods were held in June 2006 and January 2007. The measurements aimed to characterize the aerosol chemical compositions, including the gas/aerosol partitioning of inorganic compounds. The measurement program during these periods included daily or hourly measurements of the secondary inorganic components, with additional measurements of elementaland organic carbon (EC and OC) and mineral dust in $\mathrm{PM}_{1}$, $\mathrm{PM}_{2.5}$ and $\mathrm{PM}_{10}$. These measurements have provided extended knowledge regarding the composition of particulate matter and the temporal and spatial variability of PM, as well as an extended database for the assessment of chemical transport models. This paper summarise the first experiences of making use of measurements from the first EMEP
\end{abstract}

intensive measurement periods along with EMEP model results from the updated model version to characterise aerosol composition. We investigated how the PM chemical composition varies between the summer and the winter month and geographically.

The observation and model data are in general agreement regarding the main features of $\mathrm{PM}_{10}$ and $\mathrm{PM}_{2.5}$ composition and the relative contribution of different components, though the EMEP model tends to give slightly lower estimates of $\mathrm{PM}_{10}$ and $\mathrm{PM}_{2.5}$ compared to measurements. The intensive measurement data has identified areas where improvements are needed. Hourly concurrent measurements of gaseous and particulate components for the first time facilitated testing of modelled diurnal variability of the gas/aerosol partitioning of 
nitrogen species. In general, the modelled diurnal cycles of nitrate and ammonium aerosols are in fair agreement with the measurements, but the diurnal variability of ammonia is not well captured. The largest differences between model and observations of aerosol mass are seen in Italy during winter, which to a large extent may be explained by an underestimation of residential wood burning sources. It should be noted that both primary and secondary OC has been included in the calculations for the first time, showing promising results. Mineral dust is important, especially in southern Europe, and the model seems to capture the dust episodes well. The lack of measurements of mineral dust hampers the possibility for model evaluation for this highly uncertain PM component.

There are also lessons learnt regarding improved measurements for future intensive periods. There is a need for increased comparability between the measurements at different sites. For the nitrogen compounds it is clear that more measurements using artefact free methods based on continuous measurement methods and/or denuders are needed. For EC/OC, a reference methodology (both in field and laboratory) was lacking during these periods giving problems with comparability, though measurement protocols have recently been established and these should be followed by the Parties to the EMEP Protocol. For measurements with no defined protocols, it might be a good solution to use centralised laboratories to ensure comparability across the network. To cope with the introduction of these new measurements, new reporting guidelines have been developed to ensure that all proper information about the methodologies and data quality is given.

\section{Introduction}

The "Cooperative programme for monitoring and evaluation of long-range transmission of air pollutants in Europe" (EMEP) was launched in 1977, and since 1979 EMEP has been an integral component of the Convention on Long-range Transboundary Air Pollution (LTRAP). The programme has continuously been evolving as new environmental topics and priorities in air pollution control policies have entered the arena (Tørseth et al., 2012). This creates new challenges on the monitoring programme, both for the number of parameters to be monitored and for an increased density of sites. The growing demand for advanced monitoring, not least for obtaining new data for the EMEP model and other chemical transport models evaluation, is however, difficult to meet for the Parties to the EMEP Protocol, especially since these increased needs are not necessarily coupled to corresponding increase in national funding. Furthermore, to facilitate data comparability across the network, it is recommended to establish standard or reference methods for the new parameters and/or measurement methods. In an intermediate phase, before full implementation of the continuous extended mon- itoring program, shorter intensive measurement periods are a good compromise to generate datasets for model evaluation with acceptable geographical coverage. EMEP has previously arranged a number of campaigns to provide data for parameters for which the monitoring technology is too expensive or demanding to be a part of the regular programme, e.g. pilot measurements of nitrogen containing species in air in 1993-1994 (Semb et al., 1998) and the EC/OC campaign during 2002-2003 (Yttri et al., 2007). These campaigns provide useful insight to atmospheric composition and processes, and are a necessary complement to the continuous measurements. Thus in the EMEP Monitoring Strategy for 2004-2009 (UNECE, 2004), campaign measurements, defined as intensive measurements periods (IMPs) were included as a part of the EMEP monitoring programme. IMPs are also incorporated in the strategy for the present period (2010-2019) (UNECE, 2009).

In the EMEP Monitoring Strategy it is stated that full chemical speciation of particles and gas/particle distribution should be conducted at EMEP super sites (Level-2 sites) whereas more advanced measurements (Level-3) with various research focus could be carried out in shorter periods. To assist the implementation of the monitoring strategy, the EMEP Task Force on Measurements and Modelling (TFMM) recommended conducting co-ordinated intensive measurements between the Level-2 sites, and the first two sampling periods were set for June 2006 and January 2007 (UNECE, 2005). Furthermore, additional research groups were involved with more advanced research activities (Level 3 measurements) at the same sites, i.e. with continuous measurements using aerosol mass spectrometer (AMS) or wetchemistry techniques.

There were two main objectives for these first IMPs: (1) aerosol chemical speciation measurements to obtain a full mass closure for PM in several size fractions and (2) utilizing continuous online measurements to obtain high resolution, size-resolved and near artefact free measurements of gas/aerosol partitioning of inorganic species. An important motivation for these intensive measurement periods was to obtain new insight in the spatial and temporal variation in PM chemical composition in order to facilitate further development of the EMEP model as well as other chemical transport models used in Europe. The measurements provided data on mass closure of both coarse and fine particles (i.e. in $\mathrm{PM}_{10}, \mathrm{PM}_{2.5}$ and $\mathrm{PM}_{1}$ ), and this information can help explaining the existing discrepancies between modelled and observed mass of $\mathrm{PM}_{10}$ and $\mathrm{PM}_{2.5}$. Furthermore, measurements of gas/aerosol partitioning, in particular for nitrogen species, and its diurnal variation pattern are essential for improvement of our process understanding and its description in chemical transport models.

In this paper, we summarise the first experiences of making use of measurements from the first IMPs (June 2006 and January 2007), along with model results from the EMEP/MSC-W chemical transport model (Simpson et al., 
Table 1. Measurements being conducted during the EMEP intensive periods in June 2006 and January 2007.

\begin{tabular}{|c|c|c|c|c|c|c|c|c|c|c|c|c|c|}
\hline & \multirow[t]{3}{*}{ Sites } & \multirow{2}{*}{\multicolumn{2}{|c|}{ Mass }} & \multicolumn{6}{|c|}{ Daily } & \multicolumn{4}{|c|}{ Hourly } \\
\hline & & & & \multicolumn{2}{|c|}{ Inorg. } & \multicolumn{2}{|c|}{$\mathrm{EC} / \mathrm{OC}$} & \multicolumn{2}{|c|}{ Dust } & \multicolumn{2}{|c|}{ Inorg } & \multicolumn{2}{|c|}{$\mathrm{EC} / \mathrm{OC}$} \\
\hline & & Jun 06 & Jan 07 & Jun & Jan & Jun & Jan & Jun & Jan & Jun & Jan & Jun & Jan \\
\hline AT02 & Illmitz & $\mathrm{PM}_{10}, \mathrm{PM}_{2.5}, \mathrm{PM}_{1}$ & $\mathrm{PM}_{10}, \mathrm{PM}_{2.5}, \mathrm{PM}_{1}$ & FP & FP & & & & & & $\mathrm{SO}_{4}$ & $\mathrm{PM}_{2.5}$ & \\
\hline $\mathrm{CHO} 2$ & Payerne & $\mathrm{PM}_{10}, \mathrm{PM}_{2.5}, \mathrm{PM}_{1}$ & $\mathrm{PM}_{10}, \mathrm{PM}_{2.5}, \mathrm{PM}_{1}$ & $\mathrm{X}$ & $\mathrm{X}$ & & & & & AMS & AMS & $\mathrm{PM}_{2.5}$ & $\mathrm{PM}_{2.5}$ \\
\hline $\mathrm{CZ} 03$ & Košetice & $\mathrm{PM}_{10}, \mathrm{PM}_{2.5}$ & $\mathrm{PM}_{10}, \mathrm{PM}_{2.5}$ & & & $\mathrm{PM}_{10}$ & $\mathrm{PM}_{10}$ & & & & & & \\
\hline DE02 & Langenbrügge & $\mathrm{PM}_{10}, \mathrm{PM}_{2.5}, \mathrm{PM}_{1}$ & $\mathrm{PM}_{10}, \mathrm{PM}_{2.5}, \mathrm{PM}_{1}$ & FP & & & & & & & & & \\
\hline DE03 & Schauinsland & $\mathrm{PM}_{10}, \mathrm{PM}_{2.5}$ & $\mathrm{PM}_{10}, \mathrm{PM}_{2.5}$ & FP & & & & & & & & & \\
\hline DE07 & Neuglobsow & $\mathrm{PM}_{10}, \mathrm{PM}_{2.5}$ & $\mathrm{PM}_{10}, \mathrm{PM}_{2.5}$ & FP & & & & & & & & & \\
\hline DE44 & Melpitz & $\mathrm{PM}_{10}, \mathrm{PM}_{2.5}, \mathrm{PM}_{1}$ & & $\mathrm{X}$ & $\mathrm{X}$ & $\mathrm{X}$ & $\mathrm{X}$ & & & & AMS & & AMS \\
\hline DK41 & Lille Valby & $\mathrm{PM}_{10}, \mathrm{PM}_{2.5}, \mathrm{PM}_{1}$ & $\mathrm{PM}_{10}, \mathrm{PM}_{2.5}, \mathrm{PM}_{1}$ & & & & & & & & & & \\
\hline ES1778 & Montseny & $\mathrm{PM}_{10}, \mathrm{PM}_{2.5}, \mathrm{PM}_{1}$ & $\mathrm{PM}_{10}, \mathrm{PM}_{2.5}, \mathrm{PM}_{1}$ & $\mathrm{X}$ & $\mathrm{X}$ & $\mathrm{X}$ & $\mathrm{X}$ & $\mathrm{X}$ & $\mathrm{X}$ & & & & \\
\hline FI17 & Virolahti II & $\mathrm{PM}_{10}, \mathrm{PM}_{2.5}, \mathrm{PM}_{1}$ & $\mathrm{PM}_{10}, \mathrm{PM}_{2.5}, \mathrm{PM}_{1}$ & $\mathrm{X}$ & $\mathrm{X}$ & & & & & & & & \\
\hline GB33 & Bush & & & & & & & & & AMS & & & \\
\hline GB36 & Harwell & $\mathrm{PM}_{10}, \mathrm{PM}_{2.5}$ & & & & & & & & IC & & $\mathrm{PM}_{10}$ & \\
\hline GB48 & Auch. Moss & & & & & & & & & IC & IC & & \\
\hline IE31 & Mace Head & $\mathrm{PM}_{2.5}$ & & & & & & & & AMS & & AMS & \\
\hline IT01 & Montelibretti & $\mathrm{PM}_{10}, \mathrm{PM}_{2.5}$ & $\mathrm{PM}_{10}, \mathrm{PM}_{2.5}$ & $\mathrm{X}$ & $\mathrm{X}$ & $\mathrm{X}$ & $\mathrm{X}$ & $\mathrm{X}$ & $\mathrm{X}$ & & & & \\
\hline IT04 & Ispra & $\mathrm{PM}_{10}, \mathrm{PM}_{2.5}$ & $\mathrm{PM}_{10}, \mathrm{PM}_{2.5}$ & $\mathrm{PM}_{2.5}$ & $\mathrm{PM}_{2.5}$ & $\mathrm{PM}_{2.5}$ & $\mathrm{PM}_{2.5}$ & & & $\mathrm{IC}$ & IC & & \\
\hline NL11 & Cabauw & $\mathrm{PM}_{10}, \mathrm{PM}_{2.5}$ & $\mathrm{PM}_{10}, \mathrm{PM}_{2.5}$ & & & & & & & IC & IC & & \\
\hline NO01 & Birkenes & $\mathrm{PM}_{10}, \mathrm{PM}_{2.5}, \mathrm{PM}_{1}$ & $\mathrm{PM}_{10}, \mathrm{PM}_{2.5}, \mathrm{PM}_{1}$ & $\mathrm{X}$ & $\mathrm{X}$ & $\mathrm{X}$ & $X$ & & & & & & \\
\hline
\end{tabular}

FP: Filterpack; X:. Speciation in two or three sizes size fractions; AMS: Aerodyne Mass Spectrometer; IC: SJAC/MARGA/GREAGEOR (water soluble inorganic ions); OM: Organic mass.

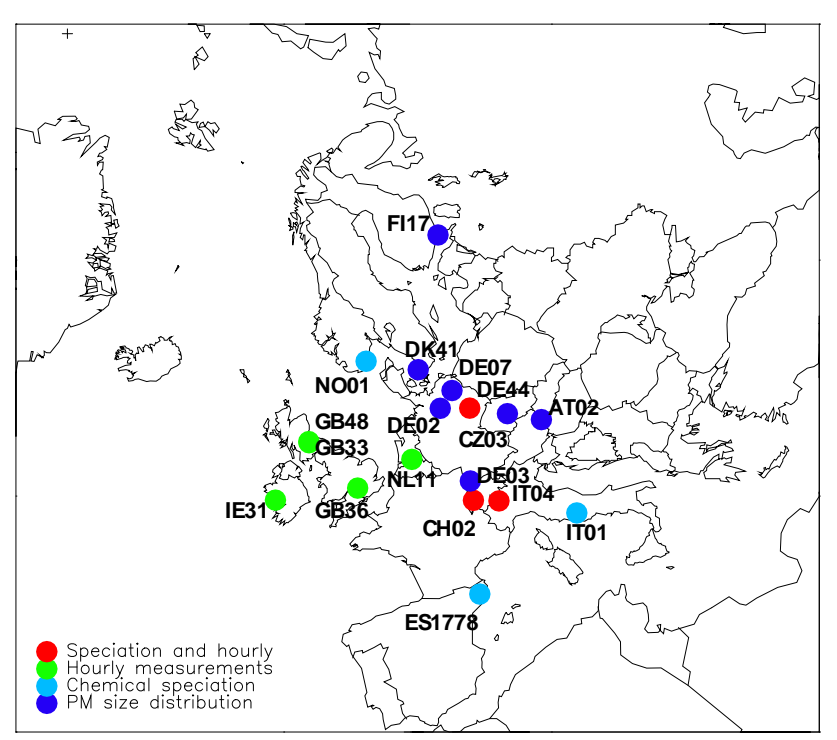

Fig. 1. Sites that took part in the EMEP intensive measurement periods in June 2006 and/or January 2007.

2012, here we use version $\mathrm{rv} 4 \beta$ ), to characterise aerosol composition. We investigated how the PM chemical composition varies between the summer and the winter month and geographically. The main results of comparison of intensive measurements with model calculations are presented and discussed, along with the consideration of encountered problems and data inconsistencies.

\section{Methodology}

\subsection{Measurement programme, sites and methods}

The first EMEP IMPs lasted from 1 to 30 of June 2006 and from 8 of January to 4 of February 2007. The measurement programme at the various sites is described in Table 1, and the locations of the sites are shown in Fig. 1. Several sites measured aerosol mass concentrations in three size fractions, $\mathrm{PM}_{1}, \mathrm{PM}_{2.5}$, and $\mathrm{PM}_{10}$, though not all of them provided the full chemical speciation. Only data from sites with PM chemical composition including at least both secondary inorganic aerosols and carbonaceous matter are selected for comparison with the EMEP model results for chemical composition. In addition, some of the continuous measurements are used to evaluate model calculated diurnal variation of gaseous and aerosol nitrogen compounds. For a more comprehensive analysis of the hourly data, the reader is referred to Nemitz et al. (2012). The measurements are compared with the average concentrations predicted by the EMEP model for the model grid cell, within which the site is located. Although EMEP measurement sites are selected to represent the rural regional background, it is recognised that in some cases the site is not always representative for the whole grid cell, i.e. IT04 which is situated close to the south eastern border of the cell, is more influenced by regional pollution from the Po valley compared to the grid cell on average.

All the data reported from these intensive periods are available from the EMEP data base (http://ebas.nilu.no). An overview of the methods used for chemical composition measurements is provided in Table 2. The methods, as well as some known artefacts and data inconsistencies are briefly described below. 
Table 2. Methods in field and laboratory for sites with chemical composition of daily measurements (manual method) in $\mathrm{PM}_{10}$ and $\mathrm{PM}_{2.5}$ of inorganic and organic components.

\begin{tabular}{|c|c|c|c|c|c|}
\hline \multirow[t]{2}{*}{ Site } & \multicolumn{2}{|l|}{ Field methods } & \multicolumn{2}{|c|}{ Analytical method } & \multirow[b]{2}{*}{ Mineral dust } \\
\hline & Sampler & Mass & Inorganic & $\mathrm{EC} / \mathrm{OC}$ & \\
\hline $\mathrm{CH} 02$ & $\begin{array}{l}\text { Digitel DHA80. Quartz } \\
\text { filters (QMA). }\end{array}$ & $\begin{array}{l}\text { Gravimetric, } \\
\text { EN } 12341\end{array}$ & $\begin{array}{l}\text { IC (from quartz } \\
\text { filters) }\end{array}$ & $\begin{array}{l}\text { Sunset Monitor, denuder, } \\
\text { TOA/NIOSH } 5040\end{array}$ & \\
\hline DE44 & $\begin{array}{l}\text { Digitel DHA80. Quartz } \\
\text { filters (MK360). Filter } \\
\text { face velocity: } 54 \mathrm{~cm} \\
\mathrm{~s}^{-1}\end{array}$ & $\begin{array}{l}\text { Gravimetric } \\
\text { EN } 12341\end{array}$ & $\begin{array}{l}\text { IC (from quartz } \\
\text { filters) }\end{array}$ & VDI 2465 -part 2 & \\
\hline ES1778 & $\begin{array}{l}\text { Digitel DHA80 Quartz } \\
\text { filters (Schleicher and } \\
\text { Schuell, QF20). Simul- } \\
\text { taneously } \mathrm{PM}_{10}, \mathrm{PM}_{2.5} \\
\text { and } \mathrm{PM}_{1} \text { mass concen- } \\
\text { tration continuously } \\
\text { with optical particle } \\
\text { counters, corrected } \\
\text { with factors obtained } \\
\text { by the gravimetric data. }\end{array}$ & $\begin{array}{l}\text { Gravimetric, } \\
\text { EN } 12341\end{array}$ & $\begin{array}{l}\text { IC and ammo- } \\
\text { nium selective } \\
\text { electrode (from } \\
\text { quartz filters) }\end{array}$ & $\begin{array}{l}\text { Sunset analyzer } \\
\text { TOT technique, NIOSH } \\
\text { protocol }\end{array}$ & $\begin{array}{l}\text { ICP-AES and } \\
\text { ICP-MS from } \\
\text { total acidic } \\
\text { digestion of } \\
\text { quartz filters }\end{array}$ \\
\hline IT01 & $\begin{array}{l}\text { Tandem quartz filter } \\
\text { (QBQ) Filter face } \\
\text { velocity: } 54 \mathrm{~cm} \mathrm{~s}^{-1}\end{array}$ & $\begin{array}{l}\text { beta attenuation } \\
\text { method (OPSIS } \\
\text { SM200) }\end{array}$ & $\begin{array}{l}\text { IC (from Teflon } \\
\text { filters and de- } \\
\text { nuders) }\end{array}$ & $\begin{array}{l}\text { Sunset TOA NIOSH } \\
5040 . \text { Corrected for } \\
\text { positive artefact in June }\end{array}$ & $\begin{array}{l}\text { ED-XRF } \\
\text { (Teflon filters) }\end{array}$ \\
\hline IT04 & $\begin{array}{l}\text { Single quartz filter, de- } \\
\text { nuder. Filter face veloc- } \\
\text { ity: } 24 \mathrm{~cm} \mathrm{~s}^{-1}\end{array}$ & $\begin{array}{l}\text { Gravimetric, } \\
\text { quartz filter, not } \\
\text { conditioned }\end{array}$ & $\begin{array}{l}\text { IC (from quartz } \\
\text { filters) }\end{array}$ & $\begin{array}{l}\text { Sunset .TOA, EUSAAR- } \\
\text { 1. Corrected for positive } \\
\text { artefacts }\end{array}$ & \\
\hline NO01 & $\begin{array}{l}\text { Tandem quartz filter } \\
\text { (QBQ). Filter face } \\
\text { velocity: } 54 \mathrm{~cm} \mathrm{~s}^{-1}\end{array}$ & $\begin{array}{l}\text { Gravimetric, } \\
\text { quartz filter, not } \\
\text { conditioned }\end{array}$ & $\begin{array}{l}\text { IC (from quartz } \\
\text { filters) }\end{array}$ & $\begin{array}{l}\text { Sunset. TOT, EUSAAR- } \\
\text { 1. Corrected for positive } \\
\text { artefact in June }\end{array}$ & \\
\hline
\end{tabular}

\subsubsection{Aerosol mass}

The reference method for mass measurements based on gravimetry in accordance to EN 12341 (CEN, 1999) were used at most sites, though there were some exceptions. IT01 used the beta attenuation monitor (OPSIS SM200) and $\mathrm{PM}_{2.5}$ is measured with a tapered element oscillating microbalance (TEOM) at DK41. At GB36, $\mathrm{PM}_{10}$ and $\mathrm{PM}_{2.5}$ were measured with TEOM in parallel with $\mathrm{PM}_{2.5}$ gravimetric measurements. The gravimetric data are substantially higher than the TEOM measurements at this site, i.e. $\mathrm{PM}_{2.5}$ in June 2006 is $13.5 \mu \mathrm{g} \mathrm{m}^{-3}$ and $23.5 \mu \mathrm{g} \mathrm{m}^{-3}$ for TEOM and the gravimetric method, respectively. The TEOM instruments had a temperature of $50^{\circ} \mathrm{C}$ and it is expected a loss of volatile compounds. The difference is therefore probably partly due to the inherent problems of measuring semi-volatile aerosols with the TEOM and problems to define an appropriate correction factor (e.g. Hauck et al., 2004). For comparability between fine and coarse fraction, the TEOM data from GB36 have however been used, though as shown above, these should be considered as lower estimates. For ES1778 $\mathrm{PM}_{10}, \mathrm{PM}_{2.5}$ and $\mathrm{PM}_{1}$ mass concentrations were derived from continuous measurements with an optical particle counter (OPC, Grimm dust monitor 1107) using conversion factors obtained from simultaneous gravimetric analyses. $\mathrm{PM}_{10}$ and $\mathrm{PM}_{2.5}$ filter sampling was performed for gravimetric and chemical analysis at a rate of two filters per week. Quality assurance is a challenge with mass measurements because the required validation in accordance to EN12341 (CEN, 1999) of alternative measurements to the reference method is often done in urban areas and thus not necessarily representative for the EMEP sites. Furthermore, regular laboratory intercomparison of the weighing procedures has not yet been established. Work is in progress to better assess the quality of the mass measurements in EMEP.

\subsubsection{Water soluble inorganic ions}

The daily aerosol chemical speciation measurements were performed through water extraction of the aerosol filters and analysis by ion chromatography, except at ES1778 where $\mathrm{NH}_{4}^{+}$was analysed with a selective electrode, Table 2 . The filters were either of Teflon®or quartz using the regular filterpack measurements with no size cut-off and/or the water extracts from the gravimetric measurements of $\mathrm{PM}_{10}$ and $\mathrm{PM}_{2.5}$. These measurements are typically biased with possible evaporation of ammonium nitrate aerosol (negative artefact) and potential absorption of gaseous nitric acid and 
ammonia on the aerosol filter (positive artefact). The only exception is IT01, which used the reference denuder/filter method where one would expect only little, if any, bias in the gas/particle separation. For the filterpack method, the evaporation of $\mathrm{NH}_{4} \mathrm{NO}_{3}$ from the aerosol front filter will lead to the capture of additional $\mathrm{HNO}_{3}$ and $\mathrm{NH}_{3}$ on the impregnated filters and an overestimation of the gas-to-aerosol ratio, while capture of $\mathrm{NH}_{3}$ and $\mathrm{HNO}_{3}$ on the front aerosol filter will give an underestimated ratio. The sum of nitrate and sum of ammonium in the filter pack measurements are unbiased (EMEP, 2001)

The hourly inorganic measurements were either performed using an aerosol mass spectrometer (AMS) (Jayne et al., 2000; DeCarlo et al., 2006) or wet-chemistry techniques. These couple sequential sampling with a wet annular denuder (WAD) and steam jet aerosol collector (SJAC) to online ion chromatograph (IC), here deployed in three different incarnations (MARGA, GRAEGOR, WAD-SJAC; see Thomas et al., 2009). The wet chemistry techniques measure both gaseous and particulate species with a specific cutoff size $\left(\mathrm{PM}_{10}\right.$ and/or $\left.\mathrm{PM}_{2.5}\right)$. The cut-off of the AMS is characterised by $100 \%$ transmission for $70-600 \mathrm{~nm}$ particles and some transmission up to beyond $1 \mu \mathrm{m}$ and down to 30 $\mathrm{nm}$. Thus, the size of measured $\mathrm{NH}_{4} \mathrm{NO}_{3},\left(\mathrm{NH}_{4}\right)_{2} \mathrm{SO}_{4}$ and $\mathrm{NH}_{4} \mathrm{Cl}$ aerosols approximately corresponds to $\mathrm{PM}_{1}$. While the wet-chemistry instruments detect any water soluble components (much like the filter extractions), the AMS detects only aerosol components that volatilise at $600^{\circ} \mathrm{C}$, i.e. usually $\mathrm{KCl}, \mathrm{K}_{2} \mathrm{SO}_{4}, \mathrm{NaCl}, \mathrm{NaNO}_{3}$ and $\mathrm{Ca}_{2} \mathrm{NO}_{3}$ in $\mathrm{PM}_{1}$ are not detected.

Some of the components, which were measured in parallel with different methodologies, gave inconsistent results. At $\mathrm{CH} 02, \mathrm{PM}_{1}$ chemical speciation was determined from parallel filters and continuous AMS measurements. The difference was especially large for $\mathrm{NO}_{3}^{-}$, which hardly could be detected from the $\mathrm{PM}_{1}$ filters during June 2002 (Fig. 2). In January 2007 , the difference was $40 \%$, similar as for ammonium. The ammonium concentrations from filter samples were $30 \%$ lower compared with the AMS data in summer. Sulphate were similar for the two type of measurements, somewhat underestimated by the AMS in June possibly due to not detectable sulphate species (i.e. $\mathrm{CaSO}_{4}$ ) or small differences in the transmission curves of the inlets. For mass closure of $\mathrm{PM}_{2.5}$ at $\mathrm{CH} 02$ in this work, we combine the inorganic components in $\mathrm{PM}_{1}$ from filter $\left(\mathrm{SO}_{4}^{2-}\right.$, sea salts) and AMS $\left(\mathrm{NH}_{4}\right.$ and $\left.\mathrm{NO}_{3}\right)$, and the carbonaceous matter measured in $\mathrm{PM}_{2.5}$ using monitor. It is expected that most of the fine particle secondary inorganic aerosols (SIA) resided in the $\mathrm{PM}_{1}$ fraction resemble what is expected in $\mathrm{PM}_{2.5}$.

At NO01 the data is considered unreliable for the SIA components in both size fractions in January 2007. The concentration levels were very low, especially for nitrate and ammonium, dropping below the detection limit of the IC analysis in many days. The regular filterpack data (with no size cut) from the same period seems more reasonable, and we

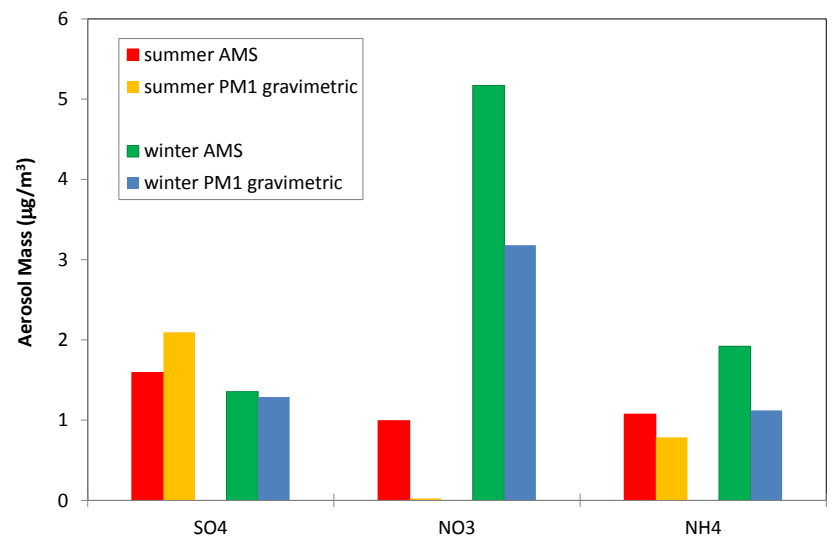

Fig. 2. Comparison of chemical speciation measurements using AMS and filters from gravimetric $\mathrm{PM}_{1}$ sampler at Payerne, $\mathrm{CH} 02$.

have therefore used these as a proxy for the nitrate and ammonium in $\mathrm{PM}_{10}$.

\subsubsection{Carbonaceous matter}

Measurement of elemental carbon (EC), organic carbon (OC) and total carbon (TC) in $\mathrm{PM}_{10}$ and $\mathrm{PM}_{2.5}$ were conducted at six sites. The quartz fibre filters used were preheated for $3 \mathrm{~h}$ at $900^{\circ} \mathrm{C}$ to minimize blank values of OC. Various protocols were applied for analysis (Table 2), thus hampering the comparability of these data.

Although the analytical approaches vary, it is generally accepted that the total carbon (TC) should be comparable. Putaud et al. (2010) estimates that the discrepancies of TC across the European measurements is smaller than $\pm 25 \%$ whilst the split between EC and OC is more site specific depending on methodology. The thermal optical analysis corrects for charring of OC during analysis, however different temperature programs are used (i.e. EUSAAR_1 and NIOSH (Table 2), which impact the split between EC/OC. Further, the VDI 2449 method provides TC levels comparable to the thermal optical methods, but overestimates EC as it does not account for charring of OC (Schmid et al., 2001; Cavalli and Putaud, 2011).

The collection of filter samples for subsequent analysis of OC is associated with positive and negative sampling artefacts. IT01 and NO01 used tandem filter set-ups (McDow and Huntzicker, 1990) operating according to the QBQapproach (quartz-fibre filter behind quartz fibre filter) to account for the positive artefact of OC. The positive artefact of OC at these two sites accounts for $30-50 \%$ of OC in June. The backup filter was not analysed in January at either of these sites, in Norway, due to very low level of OC. Thus the OC data at IT01, NO01 in January 2007 were not corrected for positive artefacts. IT04 and CH02 used a denuder to remove the gaseous organic compounds before they reach the filter. Neither of those four sites, which used denuders or the 
QBQ-approach, accounted for negative artefacts, thus they provided a low estimate of OC.

For chemical mass closure of $\mathrm{PM}_{10}$ and $\mathrm{PM}_{2.5}$ the amount of organic matter mass (OM) is usually calculated applying a conversion factor to $\mathrm{OC}$ to account for non-C components. However, in this paper we have chosen not to apply any conversion factor for OC nor EC, since the conversion factor may vary considerably between the sites (Yttri et al., 2007; Putaud et al., 2010), adding uncertainties to the comparison between model and measurements. The non-carbonaceous OM is included in what is defined as "other", and comparison with model focuses on the OC component only. The carbonaceous fraction in the PM composition should therefore be considered generally underestimated.

\subsubsection{Mineral dust}

The measurements of mineral compounds were performed using XRF at IT01 and ICP-AES and ICP-MS from solutions obtained by total acidic digestion of the filter at ES1778 (Pey et al., 2010). Mineral dust mass (DU) was derived from measurement data, using the formula suggested by Chan et al. (1997):

$\mathrm{DU}=(1.89 \cdot \mathrm{Al}+2.14 \cdot \mathrm{Si}+1.4 \cdot \mathrm{Ca}+1.2 \cdot \mathrm{K}+1.36 \cdot \mathrm{Fe}) \cdot 1.12(1)$

where all concentrations are in $\mu \mathrm{g} \mathrm{m}^{-3}$. For the other sites, water soluble calcium may be used as an indicator of mineral dust; however, that has not been applied here for the model measurement intercomparison since the model does not calculate the individual mineral components. Nevertheless, modelled dust is included in the chemical speciation calculations even at sites with no dust measurements.

\subsection{Model description}

The EMEP MSC-W chemical transport model, version rv $4 \beta$, has been used for the calculations. The full description of the model is given in Simpson et al. (2012) (for version rv4, we will note differences where relevant). The model calculation domain covers the whole of Europe, and includes a large part of the North-Atlantic and the Arctic areas. The model resolves 20 vertical layers, reaching a height of 100 $\mathrm{hPa}$. The lowest model layer is approximately $90 \mathrm{~m}$ thick. In the present calculations, the horizontal resolution of approximately $50 \times 50 \mathrm{~km}^{2}$ was used.

The EMEP model describes the emissions, chemical transformations, transport and dry and wet removal of gaseous and particulate air pollutants. The basic EMEP photo-oxidant and inorganic aerosol scheme uses about 140 reactions between 70 species (Andersson-Sköld and Simpson, 1999; Hayman et al., 2012, Simpson et al., 2012), and in addition a scheme for secondary organic aerosol (SOA), derived from Bergström et al. (2012) has been implemented. In the model, $\mathrm{SO}_{2}$ is oxidised to sulphate in the form of $\mathrm{H}_{2} \mathrm{SO}_{4}$ in the gas phase by $\mathrm{OH}$ and in the aqueous phase by $\mathrm{H}_{2} \mathrm{O}_{2}$ and $\mathrm{O}_{3}$.
In the daytime and in summer, $\mathrm{NO}_{2}$ oxidation occurs mainly through reaction with $\mathrm{OH}$, while in the night time and in winter its oxidation is predominantly by ozone on deliquescent aerosols. An important source of nitrate in the troposphere is the reaction of $\mathrm{N}_{2} \mathrm{O}_{5}$ on deliquescent aerosols, producing $\mathrm{HNO}_{3}$, which further takes part in the formation of ammonium nitrate and/or coarse nitrate on sea salt and dust particles. Ammonium sulphate is formed instantaneously from $\mathrm{NH}_{3}$ and $\mathrm{H}_{2} \mathrm{SO}_{4}$. The MARS equilibrium model (Binkowski and Shankar, 1995) is used to calculate the partitioning of inorganic species $\left(\mathrm{HNO}_{3} / \mathrm{NO}_{3}^{-}\right.$and $\left.\mathrm{NH}_{3} / \mathrm{NH}_{4}^{+}\right)$between the gas and aerosol phase as a function of relative humidity and temperature. Coarse nitrate formation from $\mathrm{HNO}_{3}$ is presently assumed to take place at a rate which depends on relative humidity.

The EMEP model combines the calculated aerosol chemical components treated by the model to predict the mass concentration of two size fractions for aerosols, fine aerosol $\left(\mathrm{PM}_{2.5}\right)$ and coarse aerosol $\left(\mathrm{PM}_{10-2.5}\right)$. The aerosol components included in the model are sulphate $\left(\mathrm{SO}_{4}^{2-}\right)$, nitrate $\left(\mathrm{NO}_{3}^{-}\right)$, ammonium $\left(\mathrm{NH}_{4}^{+}\right)$, anthropogenic elemental (EC) and organic aerosol (primary and secondary from both anthropogenic and biogenic sources), sea salt and mineral dust (from anthropogenic sources and windblown).

Ammonium nitrate is assumed to be all associated with $\mathrm{PM}_{2.5}$. While all ammonium is assumed to be solely in the fine fraction (as ammonium nitrate or ammonium sulphates), calculated coarse $\mathrm{NO}_{3}^{-}$is assumed to be evenly split between $\mathrm{PM}_{2.5}$ and $\mathrm{PM}_{10-2.5}$ so that half of the coarse $\mathrm{NO}_{3}^{-}$mass is attributed to each size fraction. In the model, coarse nitrate represents nitrate aerosol formed on sea salt and mineral dust. When comparing calculated $\mathrm{PM}_{2.5}$ with observations, the model accounts that a portion of the nitrate associated with sea salt and dust resides on aerosols with diameters smaller than $2.5 \mu \mathrm{m}$, and thus contributes to $\mathrm{PM}_{2.5}$ mass. In this rv $4 \beta$ model version, the Mass Median Diameter (MMD) of coarse nitrate is assumed to be $2.5 \mu \mathrm{m}$ (whereas fine nitrate has MMD of $0.33 \mathrm{um}$ ), and we assume that $50 \%$ of this is in the fine $\left(\mathrm{PM}_{2.5}\right)$. This treatment reflects an assumption that most coarse nitrate is being formed on sea-salt, with condensation occurring at the lower end of the coarse particle mode, which has highest surface-area (see e.g. Pakkanen et al., 1996, Simpson et al., 2012). On the other hand, coarse nitrate formed on dust particles may have MMD larger than sea salt associated nitrate (e.g. $3.8 \mu \mathrm{g}$ as in data by Pakkanen et al., 1996). Thus, in the areas of large influence of mineral dust, the EMEP model will probably overestimate nitrate in $\mathrm{PM}_{2.5}$. This split between $\mathrm{PM}_{2.5}$ and $\mathrm{PM}_{2.5-10}$ for nitrate is clearly rather uncertain, and currently work is in progress to implement an explicit formation of nitrate on sea salt and dust aerosols, which in principal should lead to a sounder process description. (In version rv4, a larger MMD of $3 \mu \mathrm{m}$ was assumed for coarse nitrate, giving a lower fraction of coarse $\mathrm{NO}_{3}$ in the $\mathrm{PM}_{2.5}$ range). 
Aerosol water is calculated as function of the ambient relative humidity and temperature based on PM chemical composition. For consistent comparison with observations, the model also estimates the water content in $\mathrm{PM}_{10}$ and $\mathrm{PM}_{2.5}$ gravimetric mass determined according to the EN 12341 standard (CEN, 1999), i.e. at $20^{\circ} \mathrm{C}$ temperature and $50 \%$ relative humidity (Tsyro, 2005). Aerosol water is necessary to estimate the total mass, but in the model the water content calculated is not influencing the partitioning between fine and coarse particles, nor the deposition processes. Dry deposition parameterisations for aerosols are calculated as in Simpson et al. (2012), accounting for aerodynamic and laminar sub-layer resistances and also for gravitational settling of larger particles. Meteorology and land-use dependent dry deposition velocities are calculated for the different aerosol size fractions. Wet scavenging is treated with simple scavenging ratios, taking into account in-cloud and below-cloud processes. The scavenging ratios for aerosols reflect the component's solubility, and size differentiated collection efficiencies are employed in below-cloud aerosol washout.

The model calculations presented in this work were performed using emission data from the EMEP emission database (http://www.ceip.at/emission-data-webdadab). The split of primary fine PM emissions to carbonaceous and inorganic mass, and the remaining primary component was made based on the estimates by Kupiainen and Klimont (2007) and Z. Klimont (personal communications, 2010).

Three-hourly meteorological fields from the ECMWF-IFS model (http://www.ecmwf.int/recearch/ifsdocs/) were used to drive the calculations of pollutant atmospheric transport.

\section{Results and discussion}

\subsection{Aerosol mass and chemical composition}

All the sites with mass measurements in two or three size fractions have been compared to assess the variations in size distribution, Fig. 3. For all size fractions, the lowest concentrations of PM are seen in the Nordic countries and the highest in Italy. The aerosol mass was in general somewhat higher in June compared to January for all size fractions, except at AT02, CH02 and IT01, and at IT04 for $\mathrm{PM}_{2.5}$, where the winter concentrations are somewhat higher. At the Italian sites, the high PM concentrations in winter compared to summer are mainly attributed to the high carbonaceous aerosol loading in winter (chapter 3.1.2). At IT04 and CH02 also enhanced ammonium nitrate was observed in January 2007. Such differences were already documented by Lanz et al. $(2007,2008)$ for an urban background station in Switzerland. It should be noted that the during winter the increase pollution episodes are often due to worse pollution dispersion in winter, thus bad vertical mixing.

Measured $\mathrm{PM}_{10}$ and $\mathrm{PM}_{2.5}$ mass have been compared with the EMEP model, and scattered plots are seen in Fig. 4. The
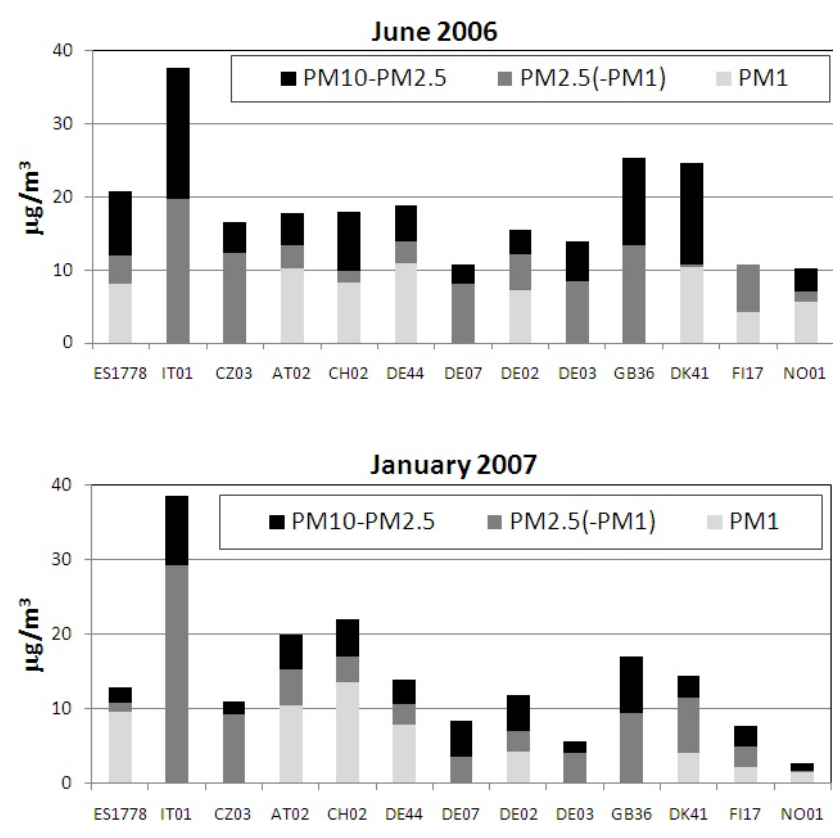

Fig. 3. Size distribution of the aerosol mass during the EMEP intensive measurement periods. Note that not all the sites have $\mathrm{PM}_{1}$ measurements. $\mathrm{PM}_{2.5}\left(\mathrm{PM}_{1}\right)$ is the difference between $\mathrm{PM}_{2.5}$ and $\mathrm{PM}_{1}$ for those sites having both these measurement, otherwise it is representing the $\mathrm{PM}_{25}$ fraction.

model calculated $\mathrm{PM}_{10}$ and $\mathrm{PM}_{2.5}$ concentrations are mostly within $30 \%$ of observed values. The model gives somewhat lower $\mathrm{PM}_{2.5}$ and $\mathrm{PM}_{10}$ mass compared to measurements, but the bias is in general quite small (between $4 \%$ and $19 \%$ ). The exception is $\mathrm{PM}_{2.5}$ in January 2007, where the model estimates $34 \%$ less than the measurements. The spatial distribution of both $\mathrm{PM}_{2.5}$ and $\mathrm{PM}_{10}$ is better reproduced by the model in June 2006 compared to January 2007 (as shown by correlation coefficients in Fig. 4), though different number of sites are included in the scatter-plots and statistics.

The fine/coarse ratio is quite similar for the two periods. On average $\mathrm{PM}_{1}$ and $\mathrm{PM}_{2.5}$ are about $50 \%$ and $70 \%$ of $\mathrm{PM}_{10}$, respectively for both seasons. However, there are large variations between the sites, $\mathrm{PM}_{1}$ ranging from $30-75 \%$ of $\mathrm{PM}_{10}$ in winter (less spread in summer), while the $\mathrm{PM}_{2.5}$ fraction of $\mathrm{PM}_{10}$ range from about $40 \%$ to almost $100 \%$ in both periods. Most sites have larger fractions of coarse particles in summer than winter probably due to bigger concentrations of coarse particles like mineral dust and primary biological aerosols particles (PBAP) in summer (e.g. Yttri et al., 2011; Querol et al., 2009). The measurements presented here are limited in time and space, and thus it is difficult to draw general conclusions from them. For further details on the regional mass and chemical composition measurements, the reader is referred to the EMEP PM reports and assessments (e.g. Tsyro et al., 2011a; EMEP, 2007) and the assessments of the European aerosol phenomenology by Putaud et al. (2004, 2010). In the regular EMEP data (Tsyro et al., 

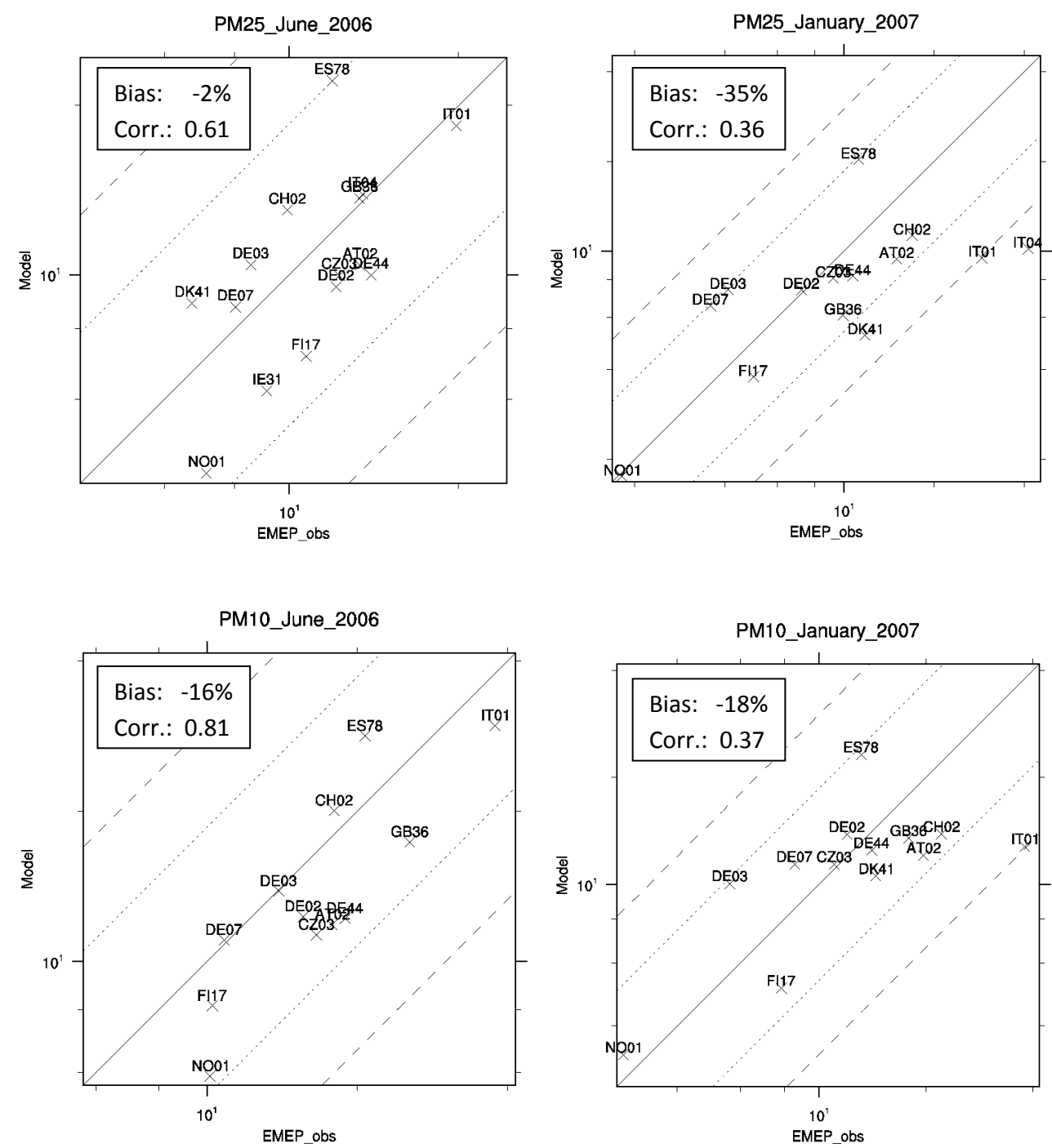

Fig. 4. Scattered plot of model and measured $\mathrm{PM}_{1} 0$ and $\mathrm{PM}_{2} .5$ mass during the EMEP intensive measurement periods.

2011a), the highest $\mathrm{PM}_{2.5} / \mathrm{PM}_{10}$ is commonly seen for central European sites, which are relatively more influenced by anthropogenic sources. In contrast, mineral dust in the south of Europe and PBAP in northern Europe contribute relatively more to the coarse fraction of $\mathrm{PM}_{10}$.

In order to explain the discrepancies between calculated and observed PM masses, we look closer at the individual aerosol components forming PM. The chemical composition of PM calculated with the EMEP model has been compared with PM mass closure data from the intensive periods for the sites reporting both inorganic and carbonaceous components, in total six sites. Figure 5 compares observed and calculated chemical composition of $\mathrm{PM}_{10}$ and $\mathrm{PM}_{2.5}$, averaged over each of the measurement periods, and displayed in four panels. Each panel shows a pairs of bar-diagrams for each of the sites: observations (left) and model results (right). The heights of the bars correspond to the measured or calculated PM concentration.

The observation and model data are in general agreement regarding the main features of $\mathrm{PM}_{10}$ and $\mathrm{PM}_{2.5}$ composition in different geographical locations and the relative contribution of the individual aerosol components. The results are fairly consistent with respect to the specifics of PM composition in the summer and winter month, and different size fractions. Organic carbon, together with sulphates in summer and nitrate in winter, appear the most important PM constituents. Mineral dust becomes dominating in $\mathrm{PM}_{10}$ at the southern sites in June 2006. It should be noted that there are fundamental limitations in how well the model (on a $50 \times 50 \mathrm{~km}^{2}$ grid) and measurements (from one point) can be expected to compare, due to the large temporal and spatial variability of atmospheric aerosols, their size distributions, chemical and physical properties, chemical formations and 

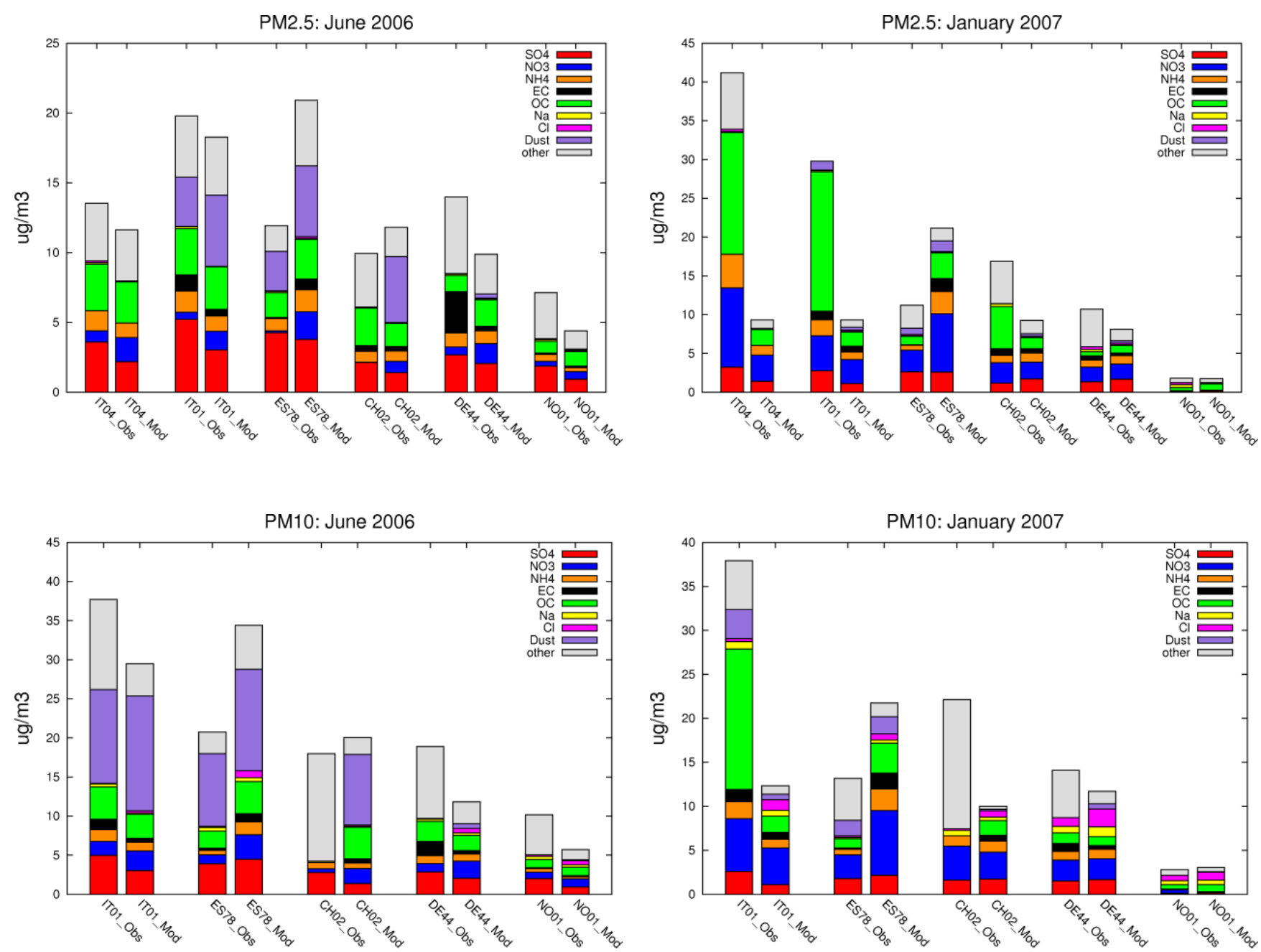

Fig. 5. Observed and modelled chemical composition of $\mathrm{PM}_{10}$ (bottom) and $\mathrm{PM}_{2.5}$ (top) for June 2006 (left) and January 2007 (right), from observations and model results. "Other" denotes not determined PM mass in measurements, and particle water + missing carbonaceous matter (OM-OC) in calculations. Note: (1) Full mineral composition was measured only at IT01 and ES17, (2) Very few days (1-6) with data at ES1778, besides different coverage for different components; (3) measured $\mathrm{PM}_{2.5}$ speciation at CH02 is based on daily SIA in PM 1 and hourly EC/OC in $\mathrm{PM}_{2.5}$ data; (4) measured nitrate and ammonium in $\mathrm{PM}_{10}$ at NO01 in January 2007 are from filterpack.

transformations, etc. More detail discussions of PM individual components are given in the next sections.

As seen for all the sites with mass measurements discussed above (Fig. 4), the model tends to predict lower concentrations of $\mathrm{PM}_{10}$ and $\mathrm{PM}_{2.5}$ compared to measurements for most of these sites except from Montseny (ES1778) for both June 2006 and January 2007 and Payerne (CH02) in June 2006 (Fig. 5 and Tables 3-4). Comparison of these results with the PM scatter-plots in Fig. 4 reveals that the estimated $\mathrm{PM}_{10}$ is lower by the model somewhat more for the smaller selection of sites with chemical composition measurements (Table 3) compared to the average for a larger selection of sites (Fig. 4). Table 3 and Figure 5 show that the low model $\mathrm{PM}_{10}$ concentrations compared to measurements are due to its underestimation of most of the individual
PM components, with the exception of nitrate and in some cases ammonium. At ES1778 (both periods), the model gives higher concentrations of all PM components compared to measurements, and consequently $\mathrm{PM}_{10}$ (Fig. 5). Regarding the performance for $\mathrm{PM}_{2.5}$, the model gives lower estimates of $\mathrm{PM}_{2.5}$ than measurements, and the difference is typically larger for the winter month than for June 2006, Fig. 5. This is consistent with the general pattern shown in Fig. 4. The highest differences for January 2007 are seen at the Italian sites, IT01 and IT04 (Figs. 4 and 5; Tables 3 and 4). One possible reason for this might be problems in resolving wintertime dispersion (e.g. very low mixing heights), but Bergström et al. (2012) and Denier van der Gon et al. (2012) concluded that there are also major uncertainties in the emission 

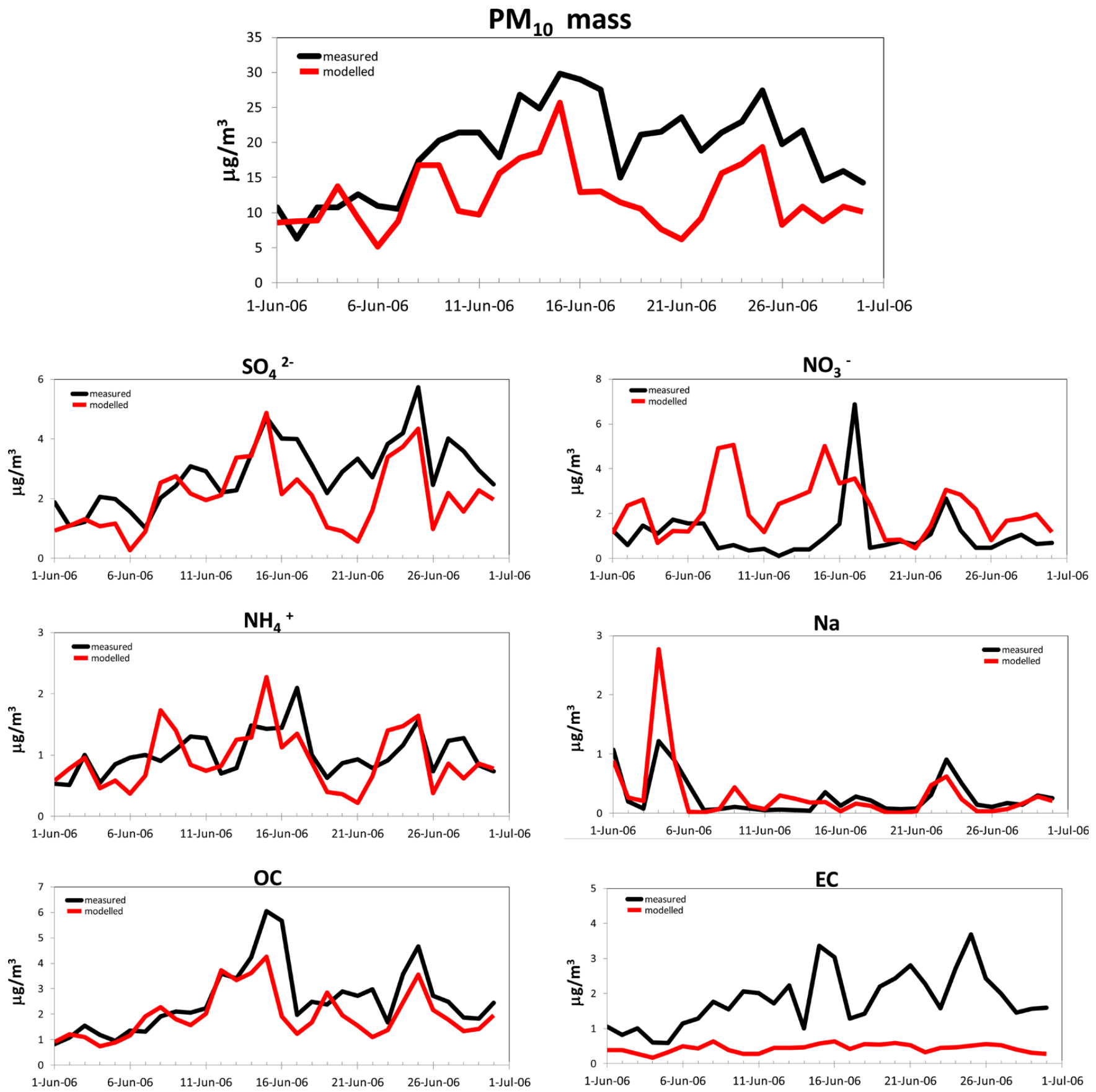

Fig. 6. Daily chemical speciation in $\mathrm{PM}_{10}$ at Melpitz (DE44) in June 2006 from measurements (black) and EMEP model (red).

inventory, likely the biomass burning component, for winter emissions in the areas around these.

The quality of the model output is certainly very dependent on good emission data. The emission estimates may have different quality depending on region. The Melpitz site (DE44) typically experiences significant higher concentration levels of $\mathrm{PM}_{10}$ and $\mathrm{PM}_{2.5}$ during easterly winds compared to westerly (Spindler et al., 2010). In June 2006, about seven days at Melpitz were influenced from this type of long- range transport and measurements show significantly higher particle mass concentrations compared with the other days. Chemical transport models have generally shown too low particle mass concentrations for long-range transport from eastern directions in Central Europe compared to measurements at DE44 (Renner and Wolke, 2006; Stern et al., 2008) indicating problems with the emissions from this region. When investigating the measurements from the EMEP IMP in more detail, one can see that the EMEP model captures the 
Table 3. Comparison statistics between model calculations and observations for $\mathrm{PM}_{10}$ component.

\begin{tabular}{lllllllllll}
\hline & & & $\mathrm{PM}_{10}$ & $\mathrm{SO}_{4}^{2-}$ & $\mathrm{NO}_{3}^{-}$ & $\mathrm{NH}_{4}^{+}$ & $\mathrm{EC}$ & $\mathrm{OC}$ & $\mathrm{Na}^{+}$ & Miner. \\
\hline IT01 & \multirow{2}{*}{2006} & Bias & -28 & -45 & 42 & -27 & -61 & -26 & -58 & 22 \\
& & $R$ & 0.92 & 0.73 & 0.7 & 0.81 & 0.3 & 0.41 & 0.72 & 0.9 \\
& \multirow{2}{*}{2007} & Bias & -66 & -58 & -31 & -49 & -42 & -88 & -17 & -81 \\
& & $R$ & 0.59 & 0.46 & 0.34 & 0.4 & 0.55 & 0.59 & 0.58 & 0.61 \\
DE44 & \multirow{2}{*}{2006} & Bias & -35 & -28 & 101 & -10 & -76 & -23 & 7 & \\
& & $R$ & 0.58 & 0.7 & 0.18 & 0.52 & 0.54 & 0.77 & 0.79 & \\
& \multirow{2}{*}{2007} & Bias & -11 & 9 & -2 & 13 & -53 & -17 & 53 & \\
& & $R$ & 0.47 & 0.55 & 0.67 & 0.52 & 0.76 & 0.61 & 0.75 & \\
NO01 & \multirow{2}{*}{2006} & Bias & -42 & -53 & 28 & -42 & 8 & 4 & -23 & \\
& & $R$ & 0.75 & 0.81 & 0.52 & 0.66 & 0.81 & 0.69 & 0.55 & \\
& \multirow{2}{*}{2007} & Bias & 18 & 25 & $-89^{*}$ & $0 *$ & 20 & 62 & 11 & \\
& & $R$ & 0.42 & 0.36 & $0.02^{*}$ & $0.06^{*}$ & 0.34 & 0.09 & 0.15 & \\
ES1778 & \multirow{2}{*}{2006} & Bias & 36 & 14 & 176 & 188 & 281 & 89 & 4 & 40 \\
& & $R$ & 0.72 & 0.55 & -0.45 & 0.77 & -0.24 & 0.15 & 0.67 & 0.84 \\
& \multirow{2}{*}{2007} & Bias & 76 & 21 & 174 & 290 & & & 147 & 9 \\
& & $R$ & 0.85 & 0.70 & 0.83 & 0.54 & & & 0.51 & 0.22 \\
\hline
\end{tabular}

Temporal data coverage: roman font cells $-90-100 \%$ coverage, italic font cells - about $30-50 \%$ coverage.

* Filterpack measurements were used (see details in the text).

Table 4. Comparison statistics between model calculations and observations for $\mathrm{PM}_{2.5}$ components

\begin{tabular}{lllllllllll}
\hline & & & $\mathrm{PM}_{2.5}$ & $\mathrm{SO}_{4}^{2-}$ & $\mathrm{NO}_{3}^{-}$ & $\mathrm{NH}_{4}^{+}$ & $\mathrm{EC}$ & $\mathrm{OC}$ & $\mathrm{Na}^{+}$ & Miner \\
\hline IT01 & \multirow{2}{*}{2006} & Bias & -7 & -42 & 161 & -27 & -59 & -8 & -71 & 44 \\
& & $R$ & 0.85 & 0.89 & 0.67 & 0.88 & 0.31 & 0.51 & 0.58 & 0.77 \\
& \multirow{2}{*}{2007} & Bias & -67 & -59 & -32 & -52 & -32 & -90 & -41 & -69 \\
& & $R$ & 0.61 & 0.41 & 0.29 & 0.43 & 0.3 & 0.56 & 0.3 & 0.44 \\
IT04 & \multirow{2}{*}{2006} & Bias & 3 & -39 & 112 & -27 & -14 & -12 & -82 & \\
& & $R$ & 0.62 & 0.66 & 0.47 & 0.50 & 0.87 & 0.78 & 0.23 & \\
& \multirow{2}{*}{2007} & Bias & -75 & -57 & -67 & -71 & -77 & -87 & -55 & \\
& & $R$ & 0.25 & 0.22 & 0.47 & 0.42 & -0.28 & 0.44 & 0.24 & \\
DE44 & \multirow{2}{*}{2006} & Bias & -29 & -23 & 154 & -10 & -89 & 64 & -60 & \\
& & $R$ & 0.57 & 0.71 & 0.22 & 0.43 & 0.27 & 0.65 & 0.79 & \\
& \multirow{2}{*}{2007} & Bias & -23 & 25 & 3 & 21 & -35 & 71 & -62 & \\
& & $R$ & 0.42 & 0.59 & 0.57 & 0.55 & 0.83 & 0.6 & 0.68 & \\
NO01 & \multirow{2}{*}{2006} & Bias & -38 & -50 & 64 & -45 & 22 & 25 & -67 & \\
& & $R$ & 0.72 & 0.84 & 0.46 & 0.69 & 0.83 & 0.78 & 0.54 & \\
& \multirow{2}{*}{2007} & Bias & -3 & 36 & $-*$ & $*$ & 50 & 100 & -89 & \\
& & $R$ & 0.02 & 0.32 & $-*$ & $*$ & 0.19 & 0.35 & 0.34 & \\
\hline
\end{tabular}

ES1778 not included due to low data capture, $\mathrm{CH} 02$ not included due to non concurrent measurements.

* Data problems at NO01.

SIA and sea salt components very well, except for one major nitrate episode on 17 June (Fig. 6). The major PM episodes (i.e. 15 June) have large contributions of carbonaceous matter, which are captured by the model. The EC levels estimated by the model are much lower than the observed values, although as noted in Sect. 2.1.3, the EC measurements at DE44 are overestimates, as they have not been corrected for charring of OC (Sect. 2.1.3; Schmid et al., 2001; Cavalli and Putaud, 2011). These examples also illustrate the importance of daily or higher resolution measurements for studying sources and comparison with model.

\subsubsection{Secondary inorganic aerosols (SIA)}

The SIA concentrations increase from the northern European site (NO01) to the central (DE44) and southern (ES1778) European sites; with even higher values found at IT01 (semirural) and IT04 (polluted Po Valley). This is in accordance with observations from the regular EMEP network where the SIA contribute on average (from 17 sites) $34 \pm 13 \%$ to the $\mathrm{PM}_{10}$ mass in 2009, with the highest contribution in central Europe (Aas and Tsyro, 2011). $\mathrm{SO}_{4}^{2-}$ and $\mathrm{NH}_{4}^{+}$seasonal variation reflects enhanced photo-oxidation rates of sulphur and 
greater abundance of ammonia in summer, whereas lower temperatures and higher relative humidity favours formation of nitrate aerosol in winter. The relative contribution of SIA and the seasonal variations are comparable in the model and measurements.

Modelled sulphate concentrations in both $\mathrm{PM}_{10}$ and $\mathrm{PM}_{2.5}$ tend to give 23 and $53 \%$ lower than observations in summer at all sites (Tables 3 and 4). The situation changes in winter, when $\mathrm{SO}_{4}^{2-}$ is even more lower than observations (57$59 \%$ ) in the southern (Italian) sites, but higher than observations by $9-36 \%$ at the sites in central and northern Europe (DE44 and NO01). At the Spanish site ES1778, the model is slightly higher than observed $\mathrm{SO}_{4}^{2-}$ in $\mathrm{PM}_{10}$ both in June 2006 and January 2007, though too few days with $\mathrm{PM}_{2.5}$ data were available at this site. The results are in general similar for $\mathrm{SO}_{4}^{2-}$ in $\mathrm{PM}_{10}$ and $\mathrm{PM}_{2.5}$, which is as expected since sulphate is mainly found in the fine fraction. However, larger underestimation and smaller overestimation by the model compared to measurements are found for $\mathrm{SO}_{4}^{2-}$ in $\mathrm{PM}_{10}$ compared to $\mathrm{PM}_{2.5}$ at DE44 and $\mathrm{NO} 01$, as only fine $\mathrm{SO}_{4}^{2-}$ is calculated by the model. Those results are in line with comparison of model with standard EMEP observations, although the bias seen here is larger (Fagerli et al., 2011). The EMEP model generally represents sulphate better than e.g. the nitrogen species when looking at a larger dataset than what is the case for the limited numbers in this study (Fagerli et al., 2011). However, the difference in performance between the different aerosol components (at least $\mathrm{SO}_{4}, \mathrm{NO}_{3}, \mathrm{NH}_{4}$ ) is rather small, Tables 3 and 4 . This can probably at least partly be attributed to uncertainties in modelling of dry and wet depositions of the aerosols, which is difficult for all of the species. Furthermore, although emission inventories of $\mathrm{SO}_{2}$ are well known, information of the temporal distribution (e.g. the summer to winter ratio) is not so well known. Model performance for $\mathrm{SO}_{4}^{2-}$ has recently been considerably improved due to improved description of cloud water acidity and also changed the temporal profile of $\mathrm{SO}_{\mathrm{x}}$ emissions.

Nitrate tends to be lower in the model compared to observations, especially $\mathrm{NO}_{3}^{-}$in $\mathrm{PM}_{2.5}$ in June 2006. The exceptions are IT01 and IT04 in January 2007, where the modelled $\mathrm{NO}_{3}^{-}$in $\mathrm{PM}_{2.5}$ is $32 \%$ and $67 \%$ lower than observations, respectively. These results are in general better than earlier model calculations, which considerably underestimated nitrate (Fagerli et al., 2011). Recent improvements have been achieved by changing to the use of the MARS equilibrium model (Binkowski and Shankar, 1995) for ammonium nitrate formation, and by accounting for a part of coarse $\mathrm{NO}_{3}^{-}$within $\mathrm{PM}_{2.5}$ mass (Sect. 2.2). Reasons for the overestimation might include incorrect size-distribution assumptions, uncertainties in the formation rates of $\mathrm{HNO}_{3}$ or coarse nitrate, and a host of factors. Explicit modelling of the sea-salt and dust reactions will be introduced in future in order to address some of these factors.
For all sites except ES1778, the modelled $\mathrm{NH}_{4}^{+}$in $\mathrm{PM}_{10}$ is by between 10 and $42 \%$ lower compared to observations in June 2006, similarly for $\mathrm{NH}_{4}^{+}$in $\mathrm{PM}_{2.5}$. It is more scattered picture in January 2007 with both higher and lower bias in both size fractions (Table 3 and 4). Modelled $\mathrm{NH}_{4}^{+}$in $\mathrm{PM}_{10}$ is much higher than observations at ES1778 in both months.

It should be noted that in the measurement data of $\mathrm{NH}_{4}^{+}$ and $\mathrm{NO}_{3}^{-}$can easily be biased. Ammonium nitrate deposited on filter samples may be prone to losses or gains due to changing equilibrium conditions during or after sampling. Such changes cannot be captured in models which treats instantaneous ammonium nitrate equilibrium. This measurement bias can clearly be illustrated with data from Montelibretti (IT01) where $\mathrm{NH}_{4}^{+}$in $\mathrm{PM}_{2.5}$ is somewhat larger than $\mathrm{NH}_{4}^{+}$in $\mathrm{PM}_{10}$ in June 2006. This is caused by, $\mathrm{NH}_{4}^{+}$ biased filter measurements of $\mathrm{NH}_{4}^{+}$in $\mathrm{PM}_{10}$ due to evaporation of $\mathrm{NH}_{4} \mathrm{NO}_{3}$, while $\mathrm{NH}_{4}^{+}$in $\mathrm{PM}_{2.5}$ is measured using a denuder filterpack system and should be unbiased. Comparison of denuder filterpack and plain filter measurements at IT01 showed that the difference in total nitrate concentration between denuder and filter measurements was $31 \%$ and $59 \%$ in summer and winter, respectively (Fig. 7). For ammonium the difference was $27 \%$ and $64 \%$ in the fine fraction. Also at $\mathrm{ES} 1778$, the ammonium is higher in $\mathrm{PM}_{2.5}$ than $\mathrm{PM}_{10}$ and this is not due to difference in methodology since both size fractions are un-denuded. These relatively high ammonium levels in $\mathrm{PM}_{2.5}$ with respect to $\mathrm{PM}_{10}$ has been widely documented before in Spain (Querol et al., 2001; Alastuey et al., 2004), and the differences have been attributed to the interaction between $\mathrm{NH}_{4} \mathrm{NO}_{3}$ and $\mathrm{NaCl}$ on the $\mathrm{PM}_{10}$ filters, given rise to the formation of $\mathrm{NaNO}_{3}$ and volatilization of $\mathrm{NH}_{3}$ and $\mathrm{HCl}$. This reaction does not take place in $\mathrm{PM}_{2.5}$, at least in a similar degree, given that $\mathrm{NaCl}$ prevails in the coarse fraction.

As the split between gas and particles are biased, the sum of nitrate $\left(\mathrm{HNO}_{3}\right.$ and $\left.\mathrm{NO}_{3}^{-}\right)$and ammonium $\left(\mathrm{NH}_{3}\right.$ and $\left.\mathrm{NH}_{4}^{+}\right)$ are usually used for model evaluation (Fagerli et al., 2011). For the four sites considered here, the model bias for total nitrate is $32 \%$ for June 2006 and $39 \%$ for January 2007, while the average bias for sum nitrate for 45 EMEP sites is - $3 \%$ and $16 \%$ respectively (data not shown), indicating that the small selection of sites in this work is not necessary giving a robust evaluation of the model performance. For further discussion of the comparison between modelled and hourly measured nitrogen species see Section 3.2.1

\subsubsection{Carbonaceous matter}

The observed ambient concentration of carbonaceous material in $\mathrm{PM}_{10}$ and $\mathrm{PM}_{2.5}$ increased from North to South for both of the measurement periods. The difference in EC and OC concentrations between sites is larger in January than in June. This is a typical observation as the concentrations generally increase during winter compared to summer for all continental sites, whereas the opposite was observed for 


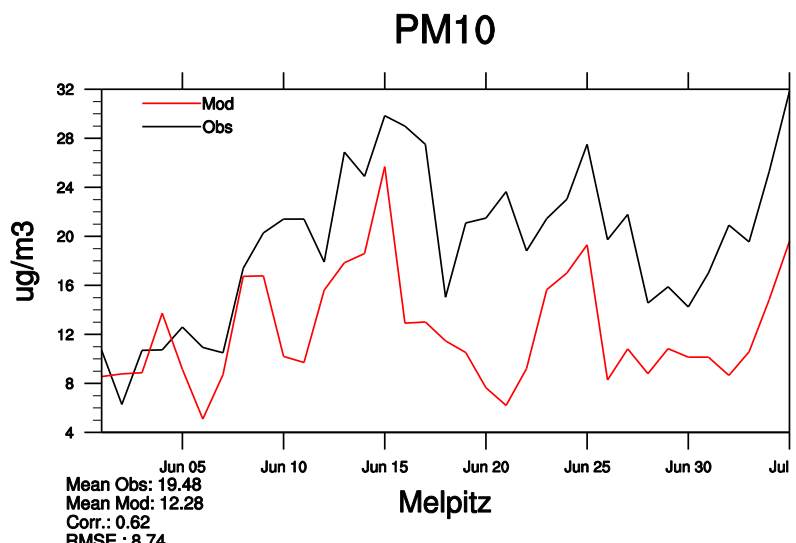

SO4_PM10

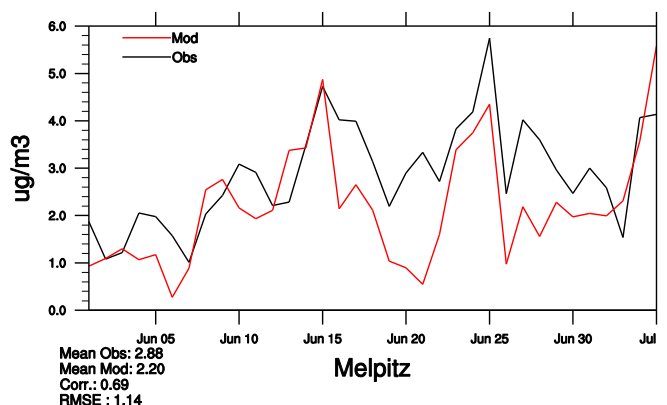

NH4_PM10

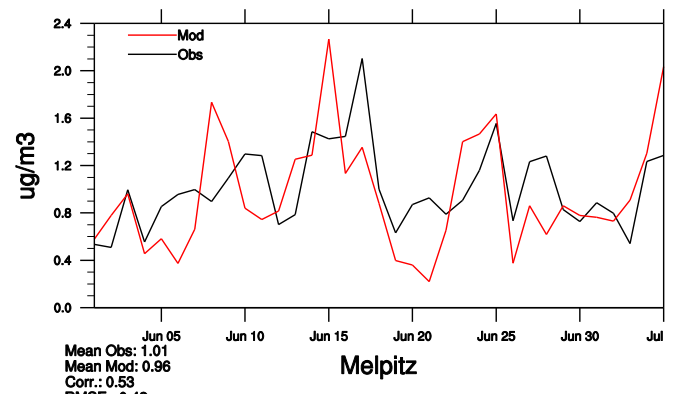

EC_PM10

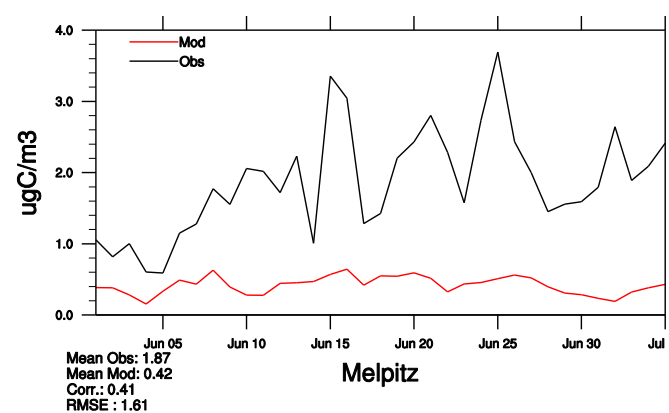

NO3_PM10

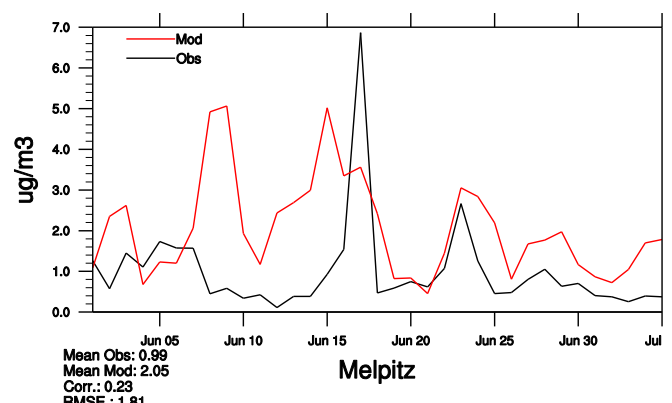

Na_PM10

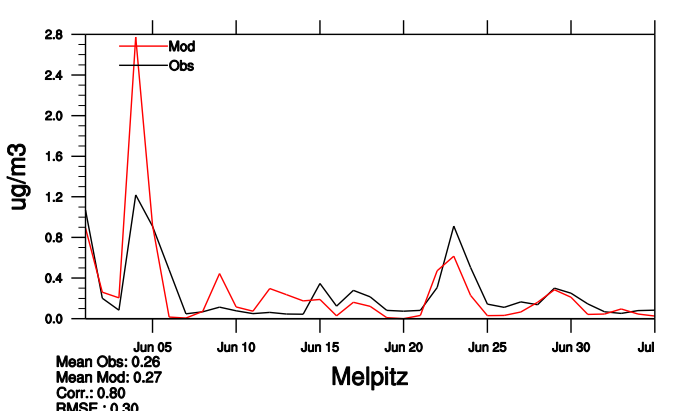

OC_PM10

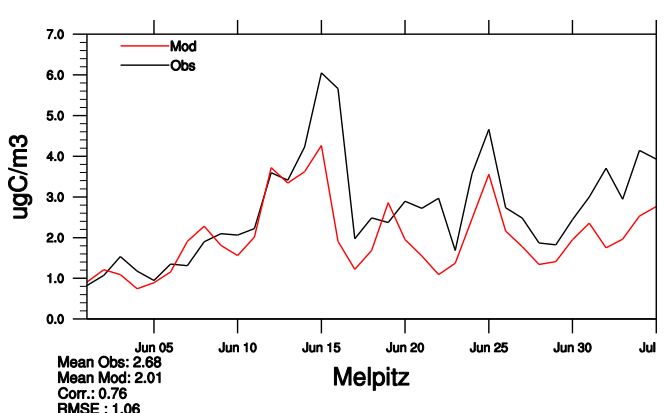

Fig. 7. Filter and denuder measurements of sulphate, nitrate and ammonium concentrations at Montelibretti, IT01. Denuder total denotes total mass of $\mathrm{SO}_{4}, \mathrm{NO}_{3}$ and $\mathrm{NH}_{4}$ without size cut off. 
the Scandinavian site Birkenes (NO01). This variation in the seasonal pattern observed for Scandinavia compared to continental Europe, has previously been described (Yttri et al., 2007; Simpson et al., 2007; Bergstöm et al., 2012).

The relatively high OC concentrations observed in Scandinavia during summer is likely due to contributions from biogenic secondary organic aerosols (BSOA) and primary biological aerosol particles (PBAP), (Yttri et al., 2007; 2011; Genberg et al., 2011). The very high OC levels in winter seen in Italy and Switzerland are most likely attributed to increased emissions from residential heating in winter (especially wood burning), and emissions from traffic combined with unfavourable dispersion conditions, suppressing the dilution of particulate emissions (Szidat et al., 2007; Lanz et al., 2008, 2010). There are indications that the wood burning emissions are probably underestimated in the emission data used in the model (Simpson et al., 2007; Tsyro et al., 2007; Bergström et al., 2012). In addition, the emission inventory did not provide emissions of coarse OC from any source.

For both $\mathrm{PM}_{10}$ and $\mathrm{PM}_{2.5}$, the model tends to give less OC compared to observations at southern sites (IT01, IT04, ES1778), but higher than observations at the northern site NO01. A bit more scattered picture in central Europe, represented by DE44. The biases, both positive and negative, are in general larger in January 2007 compared to June 2006.

Possible reasons for model OC under-prediction compared to what the observations show, could be too low emissions from e.g. residential wood burning in winter (except in Norway) (Simpson et al., 2007; Tsyro et al., 2007) and from BVOC or PBAP. There could also be missing aged primary OA contributions ("OPOA"). For in-depth analysis of the EMEP model performance for OC see Bergström et al. (2012).

There is also increasing evidence that combustion primary OC emissions are not completely non-volatile but consists of organic compounds with greatly varying volatilities (e.g. Robinson et al., 2007). Large fractions of the emissions are likely to be semi and intermediate volatility compounds (SVOC and IVOC), which are partly or completely in the gas phase at emission. These primary SVOC and IVOC species may be oxidised in the atmosphere to less volatile compounds that partition into the particulate phase and contribute to the observed OC. The IVOC part of the primary OC emissions are currently not captured in the POC or VOC emission inventories and are not included in the EMEP model version used in this study. This is expected to lead to underestimation of OC on the regional scale ${ }^{1}$. For estimates of the potential contributions from the effects of aging of primary S/IVOC emissions see Bergström et al. (2012).

\footnotetext{
${ }^{1}$ On the other hand, close to large emission sources the assumption of non-volatile POA emissions may lead to an overestimation of OC. For a regional scale model, such as EMEP, this is not likely to be a major problem.
}

The lowest EC concentrations were observed in Norway (NO01), while the levels were somewhat higher in Italy (especially at IT04). EC data from DE44 is not included in this discussion due to the biased measurement (Section 2.1.3). At IT01 the model gives lower concentrations of EC compared to observations more in summer (about $60 \%$ ) than in winter (about $40 \%$ ). However, at IT0 4 the bias was higher in winter than summer. Further, at NO01, the model gives $8 \%$ less EC than observations in $\mathrm{PM}_{10}$ by in June and $20 \%$ less EC in January, whereas for EC in $\mathrm{PM}_{2.5}$ the bias is somewhat higher (Tables 3 and 4). These results support the geographical differences in the model performance based on the EMEP EC/OC campaign data reported by Tsyro et al. (2007). In that study, the model was found to considerably underestimate EC in central and southern Europe, especially in summer, while it overestimated EC in northern Europe in winter compared to observations. The results in Tsyro et al. (2007) suggested that the large model underestimation of EC was probably due to uncertainties in traffic emissions and missing EC sources in summer. Sensitivity tests (not shown here) showed that the model EC underestimation remains at those sites even if EC removal processes were "turned off", thus supporting the suggestion about emission underestimations. The model indications of overestimations of wood burning emissions of EC in northern Europe proved reasonable and the emission estimates were decreased in the later inventories.

As a consequence of large uncertainties and missing sources of coarse EC in the emission data, the model fails to reproduce the presence of EC in the coarse fraction of $\mathrm{PM}_{10}$, as apparent from the measurements. The model predicts that the fraction of EC residing in the coarse mode is mostly smaller than $10 \%$, while that of the observations range between 10 and $50 \%$. It should be noted that some differences in the results can be due to using FINN forest fire emissions (Wiedinmyer et al., 2011) in the present calculations, whereas the GFED database was used earlier.

\subsubsection{Sea salt}

As expected, the concentrations of sea salt components $\left(\mathrm{Na}^{+}, \mathrm{Mg}\right.$ and $\left.\mathrm{Cl}^{-}\right)$show large gradients with the distance from sea. The highest sea salt sodium $\left(\mathrm{Na}^{+}\right)$levels were observed at NO01, and the levels were higher in the January 2007 than in the June 2006 due to winter storms. In Germany (DE44), the westerly winds were highly pronounced in the relatively warm January 2007, which is reflected in enhanced levels of sodium ions in model and observations. It can be noted that inland sites may measure ions found in sea salt also from other (not marine) sources. For instance, the $\mathrm{Na}^{+}$observed at IT04 in the Po Valley most probably does not originate from the sea, but from other sources, like dust and wood burning and de-icing salt on streets, which is not explicitly specified in the emissions inventory for primary 
PM. However the sodium level in IT04 is relatively low, $0.1 \mu \mathrm{g} \mathrm{m}^{-3}$.

Sodium $\left(\mathrm{Na}^{+}\right)$concentrations from the model are taken as $30.6 \%$ of calculated sea salt mass. $\mathrm{Na}^{+}$in $\mathrm{PM}_{2.5}$ is mostly lower for model compared to observations, Table 4, and the bias is in general greater in the summer (60-80\%) than in the winter $(40-60 \%)$ period, with the exception of NO01. The results are mixed for $\mathrm{Na}^{+}$in $\mathrm{PM}_{10}$ : the model result is lower than observations at IT01 and at NO01 in June 2006, and higher otherwise (Table 3). The results are not very conclusive regarding the model performance for coastal and inland sites.

The comparison with observations suggests that the model distributes too little of sea salt into the fine fraction (mostly below $15 \%$ ) compared to $20-40 \%$ in the observations. The exception is measurements data for January 2007 at NO01, suggesting that $80 \%$ of sodium is in the fine fraction ( $80 \%$ ), whereas only about $40 \%$ of $\mathrm{Cl}$ and $\mathrm{Mg}$ are in fine sea salt aerosols. This clearly indicates some problems with the sodium measurements at NO01 in January 2007. Indeed, $\mathrm{Na}^{+}, \mathrm{Cl}^{-}$and $\mathrm{Mg}^{2+}$ have similar relative $\mathrm{PM}_{2.5} / \mathrm{PM}_{10}$ ratios $(30 \%)$ in summer at NO01. For more detailed analysis of EMEP model performance for sea salt see Tsyro et al. (2011b).

We have not included chloride in the present statistical calculations as we suspected that the chloride measurements were artefact-biased due to evaporation of $\mathrm{NH}_{4} \mathrm{Cl}$ and some analytical problems measuring chloride from quartz filter. Further, it is expected that $\mathrm{Cl}^{-}$is lost when sea salt travels over continents and reacts with $\mathrm{HNO}_{3}$, releasing $\mathrm{HCl}$ (e.g. Pio and Lopes, 1998), and possible continental sources like domestic waste burning (e.g. PVC), and brown coal burning in e.g. Poland is not accounted for in the EMEP model. An indicator of these problems is the fact that the $\mathrm{Na} / \mathrm{Cl}$ ratio is often much greater compared to the typical ratio in sea water.

\subsubsection{Mineral dust}

Calculated mineral dust concentrations have only been compared with measurements at two of the sites, namely ES1778 and IT01, where all main mineral components were measured. Both observations and model show significant contributions of mineral dust to $\mathrm{PM}_{2.5}$, and especially to $\mathrm{PM}_{10}$, at those south-European sites (Fig. 5). The concentrations of mineral dust are much higher in the summer (32-42\% dust in $\mathrm{PM}_{10}$ from observations and $42-50 \%$ from calculations) than in the winter month (the corresponded values are 9-14\% and 2-3\%).

The average concentrations of mineral dust calculated by the model are mainly within $\pm 45 \%$ of observed values (the largest bias of $-81 \%$ is for mineral dust in $\mathrm{PM}_{10}$ in January 2007 at IT01). At IT01, the model shows a tendency to give lower concentrations compared to observations of mineral dust in the winter period, while higher than observations in June 2006. It should be worth noticing that 20th to 30th
June 2006, a Saharan dust transport episode reached central Italy caused an increase of crustal components in the measurements at Montelibrretti (IT01), also an increase of the unaccounted mass was registered probably due to high water content in the air masses. This event is nicely captured by the model, though slightly higher estimates of the dust load (data not shown) than the observations. The higher estimates by the model might be due to too high boundary conditions for Saharan dust. At ES1778, the dust concentrations is also somewhat higher by the model than observations, greater so in June 2006. Regarding the size fractionation of mineral dust (measured only at IT01), the results indicate that the model over-predicts dust mass in the coarse fraction for that site.

At the sites with no mineral dust measurements it is especially at Payerne (CHO2) the model results indicate that this component could be of significant importance (Fig. 5). The measurements of $\mathrm{Ca}$ and $\mathrm{K}$ confirm that there are important dust episodes at $\mathrm{CH} 02$, but it is necessary to measure other mineral components to get significant mass contribution.

\subsubsection{Not-determined PM mass}

As seen in Fig. 5, a large portion of $\mathrm{PM}_{2.5}$, and particularly $\mathrm{PM}_{10}$ mass, remains not determined (denoted as "other" in Fig. 5) in the measurement data. The undetermined PM mass is the difference between the gravimetric PM mass and the sum of masses of all identified components. The most important contributor to the fraction "other", is unaccounted non-C atoms (e.g. $\mathrm{H}, \mathrm{O}, \mathrm{N}$ ) associated with the aerosol organic matter, thus carbonaceous matter is an important part of the nondetermined mass at most of the sites. In addition, there are other factors like non determined species like mineral dust, which as mentioned above could be especially important at $\mathrm{CH} 02$. Further there is non determined: water, present on the particles at $20^{\circ} \mathrm{C}$ and $50 \%$ relative humidity (which are the equilibration conditions of PM samples as well as measurement errors (e.g. Putaud et al., 2004, 2010). In the model results "other" includes water and unaccounted non-C atoms (e.g. $\mathrm{H}, \mathrm{O}, \mathrm{N}$ )

The not-determined mass in measured PM is larger in the summer month of June 2006 than in January 2007 for all sites.

\subsection{Gas/aerosol partitioning and diurnal variation of nitrogen species}

Accurate description of nitrogen chemistry is one of the main challenges in modelling the atmospheric chemistry. In particular, partitioning of nitrogen components between gas and aerosol phases still needs improvement (Fagerli and Aas, 2008; Schaap et al., 2011). The equilibrium between gaseous nitric acid and ammonia on one side and ammonium nitrate aerosol on the other side is determined by the concentrations of $\mathrm{HNO}_{3}$ and $\mathrm{NH}_{3}$ (Seinfeld and Pandis, 2006). The emissions of ammonia vary from night to daytime, and so do the 
precursors of nitric acid and its formation rate. Furthermore, the partitioning of nitrogen species between gas and aerosol depends on meteorology, namely, temperature and relative humidity, and thus should be subject to diurnal variability. Therefore, it is clear that simultaneous measurements of the relevant nitrogen components, and in particular their diurnal variability, are crucial for understanding and adequate description of the chemical processes.

The hourly measurement data represent a unique dataset for studying the diurnal variation of gaseous and aerosol pollutants and for evaluation of the model ability to reproduce it, in particular important for the gas/particle distribution of nitrogen components. Here, we present some results for concentrations in air of gaseous ammonia and nitric acid as well as aerosol ammonium and nitrate.

Our results reveal that, in some cases the model has difficulties to accurately reproduce the observed daily concentrations of nitrogen species. Given the arguments above, it can be difficult to explain the model performance based only on the daily measurements. Therefore seeking for explanation of the model results compared to observations, we look at the average diurnal variation of $\mathrm{N}$ species at the sites with hourly measurements. For illustration, the diurnal variations of concentrations of $\mathrm{HNO}_{3}, \mathrm{NH}_{3}$, and $\mathrm{NO}_{3}^{-}$and $\mathrm{NH}_{4}^{+}$are shown in Fig. 8 for Cabauw (NL11), Harwell (GB36) and Ispra (IT04). These are chosen since all the stations were equipped with both gaseous and particulate nitrogen components and represent different regions in Europe. Comparison at the other sites with continuous measurements (Table 1) has also been done and is used in the discussion.

\subsubsection{Nitrate and nitric acid}

For the summer measurement period (June 2006), the observed diurnal variation of $\mathrm{HNO}_{3}$ concentrations has a pronounced maximum around noon, while the minimum is at night. This is fairly well reproduced by the EMEP model, though the noon peaks are often given higher by the model (Fig. 8). In the winter month of January 2007, the $\mathrm{HNO}_{3}$ concentrations are very low and the diurnal variation is less pronounced compared to summer. It is interesting to note that the variation of daily concentration throughout the month is larger than the diurnal variation, indicating the importance of pollution episodes.

For nitrate in $\mathrm{PM}_{2.5}$, two model curves are shown in Fig. 8 for NL11 and GB36: one curve represents ammonium nitrate aerosol $\left(\mathrm{NH}_{4} \mathrm{NO}_{3}\right)$, which is mostly smaller than $1 \mu \mathrm{m}$, and the other one represents nitrate in $\mathrm{PM}_{10}$, which is the sum of $\mathrm{NH}_{4} \mathrm{NO}_{3}$ and coarse $\mathrm{NO}_{3}^{-}$. As explained in section 2.2, nitrate in $\mathrm{PM}_{2.5}$ is presently calculated as the sum of $\mathrm{NH}_{4} \mathrm{NO}_{3}$ and half of coarse $\mathrm{NO}_{3}^{-}$mass, though the uncertainty of this approximation is well recognized. Thus, modelled $\mathrm{NO}_{3}^{-}$in $\mathrm{PM}_{2.5}$ concentration should be lying somewhere between the two model curves in Fig. 8. In general, the diurnal profile of nitrate aerosol in January 2007 is modelled well, with higher values during night (i.e. at DE44, CH02 and NL11). The exception is Auchencorth Moss (GB48), where the observed nitrate in $\mathrm{PM}_{2.5}$ peaks during day, but the concentration level is low and the nitrate in $\mathrm{PM}_{10}$ shows slightly higher levels at night (data not shown). The model reproduces well the diurnal profile of $\mathrm{PM}_{2.5}$ nitrate at GB48, though lower than observations, similar bias at IT04 in January 2007 (Fig. 8). The modelled and measured diurnal cycle for nitrate during June 2006 agree well for NL11, IT04 and GB36 and reasonable at GB48.

As discussed above, the model tends to somewhat overpredict nitric acid concentrations in June 2006 compared to observations, while it under-predicts concentrations in January 2007. During June 2006, nitrate is in general lower in the model results compared to hourly data, though less so at GB36. However, when all intensive data is considered, the model is in general higher than observations for nitrate in June 2006 (Fig. 9; Tables 2 and 3). There is a tendency that nitrate in $\mathrm{PM}_{1}$ is less biased, and the model even show lower concentrations than observations (Fig. 9), indicating that there is a somewhat too high formation rate of nitrate directly from $\mathrm{HNO}_{3}$ (supposed to account for the reaction on sea salt and dust). In the winter, the modelled and measured levels of nitrate are in good agreement. These results are in agreement with what is found when the EMEP model results are compared to the 'standard' EMEP measurements (Fagerli et al., 2011).

\subsubsection{Ammonia and ammonium}

For June 2006, both the modelled and measured diurnal cycle of $\mathrm{NH}_{3}$ have a usually a maximum in early morning, and in general somewhat higher $\mathrm{NH}_{3}$ concentrations during day time than night time, except at Ispra (IT01) where the modelled $\mathrm{NH}_{3}$ show little diurnal variation. The same pattern can be found for January 2007, although the diurnal variation is somewhat weaker in the measurements, and somewhat more pronounced in the model results. The diurnal cycle of ammonia is governed by several factors like (1) the diurnal cycle of the emissions, (2) the conversion to ammonium (ammonium nitrate and ammonium sulphate) and (3) dry deposition and atmospheric stability. Agricultural sources tend to emit more ammonia during day time (due to e.g. higher temperatures, more wind/mixing), thus for sites that are close to source areas, the stronger source during day time may outcompete the larger boundary layer mixing. This is not exactly reflected by the variation of $\mathrm{NH}_{3}$ in NL11, as the average highest concentrations are seen at night and most pronounced in June. This may be due to nearby farms with forced ventilation, which emit the same quantity at day and night. With a thinner mixing layer at nighttimes the regional concentration will be higher. However, it should be noted that a strong $\mathrm{NH}_{3}$ peak during a single night (from 19 to 20 June), caused these high average concentration during night, whereas the median diurnal cycle of $\mathrm{NH}_{3}$ shows the expected peak in early morning 
Harwell (GB36), June 200
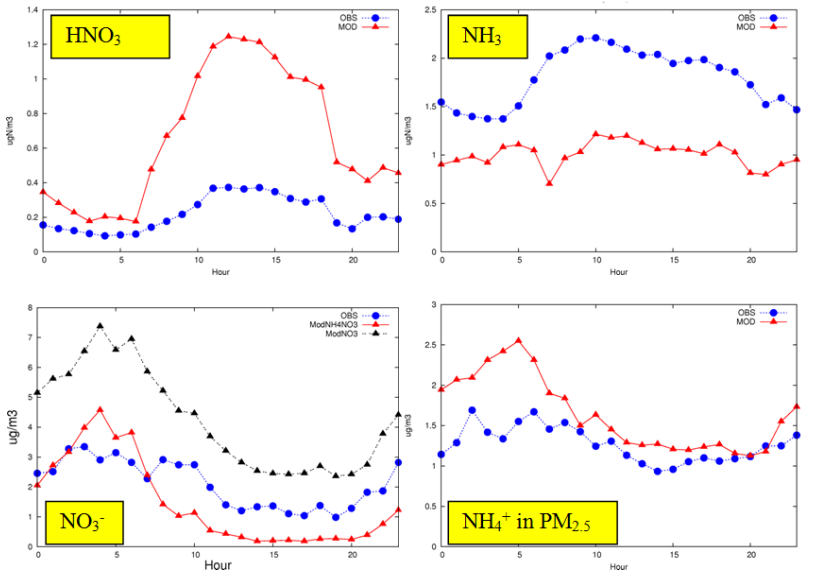

Cabauw (NL11), January 2007
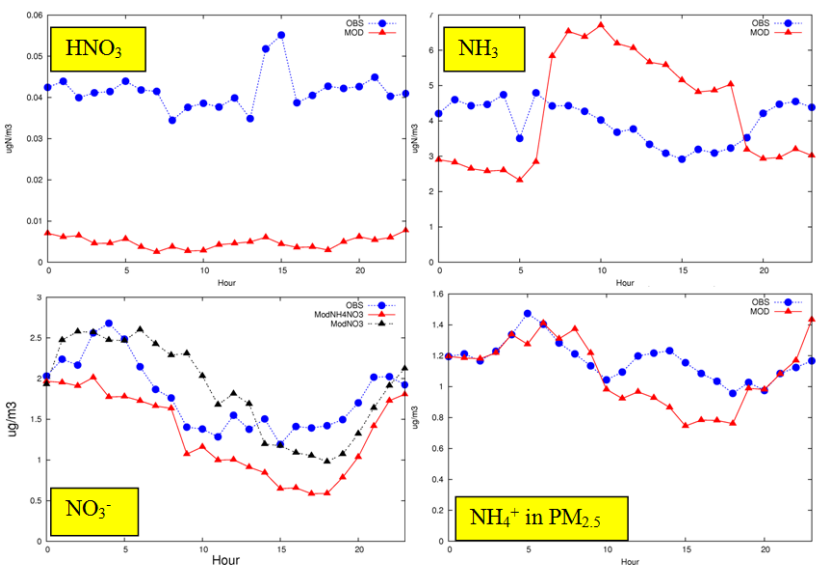

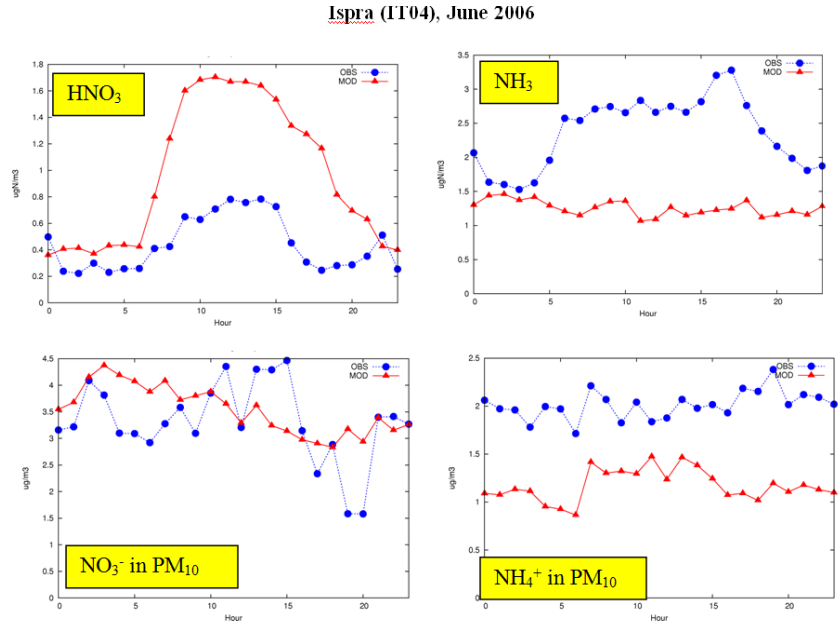

Ispra (IT04), January 2007
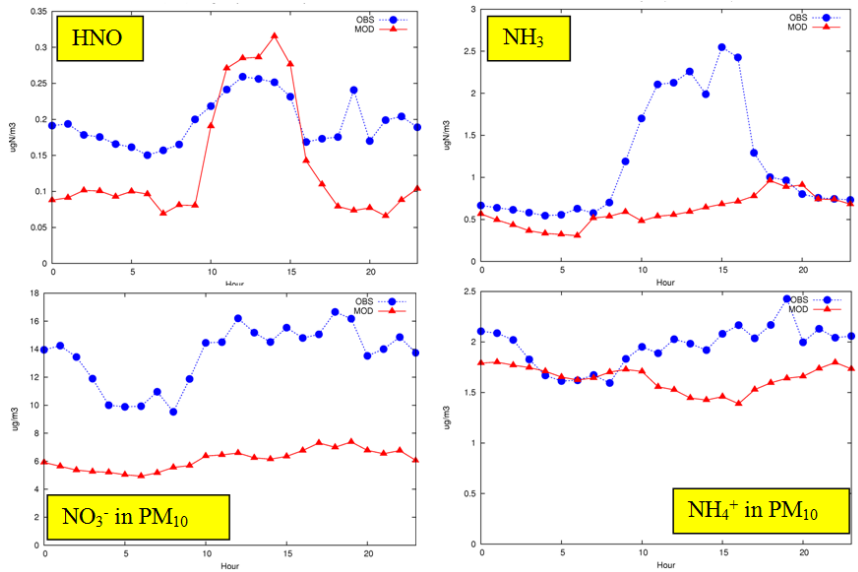

Fig. 8. Diurnal variations of gaseous and particulate nitrogen species from some of the intensive measurements compared with the EMEP model. Measured ammonium and nitrate in $\mathrm{PM}_{2.5}$ at Cabauw (NL11) and Harwell (GB36) while in $\mathrm{PM}_{10}$ at Ispra (IT04) Note: there are two curves showing model results of nitrate at Cabauw and Harwell: for ammonium nitrate $\left(\mathrm{NH}_{4} \mathrm{NO}_{3}\right)$ (red) and nitrate in $\mathrm{PM} 10$, (mod NO3) which is the sum of $\mathrm{NH}_{4} \mathrm{NO}_{3}$ and coarse $\mathrm{NO}_{3}^{-}$(black) (see explanations in Sect. 3.2.1).
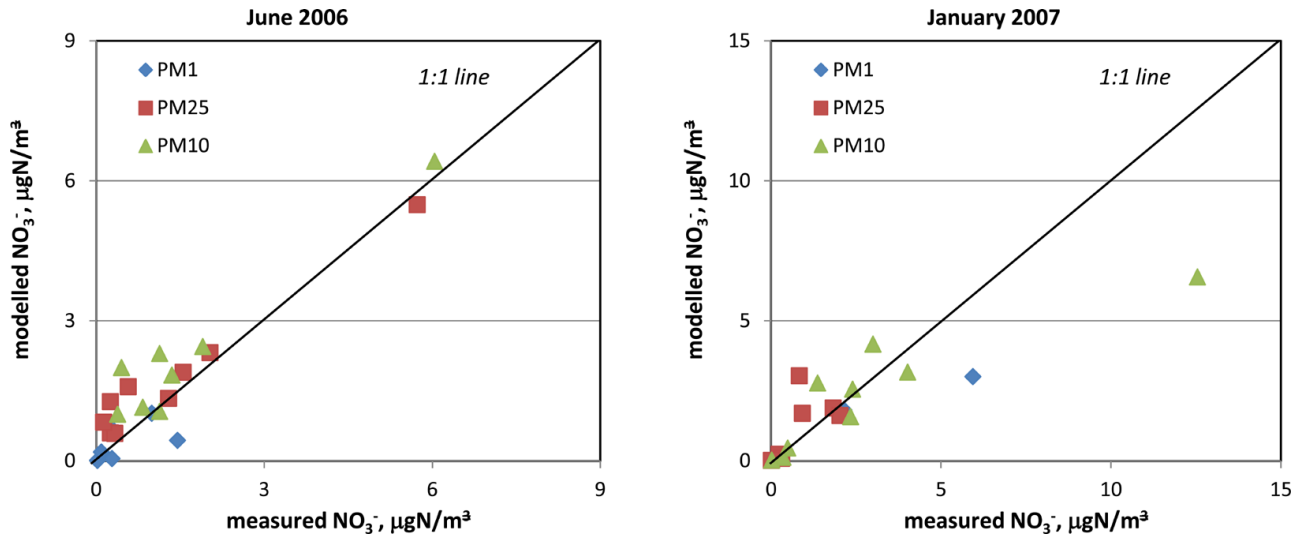

Fig. 9. Modelled and measured nitrate in the different size fractions for June 2006 (left) and January 2007 (right). Note different scale for the two periods. 
hours at NL11 (as in the model results) as seen when averaging for a complete year (Schaap et al., 2011). In the EMEP model, we assume that emissions during day time are a roughly a factor of two higher than at night time throughout the whole year. In reality, the day-night variation might be very different from site to site, depending e.g. on the type of agricultural sources and the meteorology. In order to provide a better diurnal variation of ammonia emissions (and thus also for ammonia concentrations) the EMEP model could be coupled to a dynamic, mechanistic ammonia emission model where the diurnal variation of emissions would depend on temperature, wind and type of agricultural activity. Such an emission module has already been implemented for Denmark and the extension to a European module is on its way (Skjøth et al., 2011). Similarly, the introduction of a bi-directional exchange module (Massad et al., 2010) would result in higher $\mathrm{NH}_{3}$ concentrations during the day when deposition is reduced due to elevated compensation points.

The modelled diurnal cycle of ammonium at Cabauw (NL11) and Harwell agrees well with measurements with the highest values found at night (similarly as nitrate) (Fig. 8). At Auchencorth Moss (GB48), June 2006, measured ammonium is found to peak in early afternoon at the same time as $\mathrm{NH}_{3}$ peaks. In the model however, ammonium peaks in early morning. The failure to describe ammonium at this site is probably due to the failure to describe the $\mathrm{NH}_{3}$ ammonia emission diurnal variability. In January 2007, however, the diurnal cycle of modelled and measured ammonium agree well, although the level of ammonium is somewhat overpredicted by the model compared to observations. Both measurements and model results show a peak in the early morning. At Ispra (IT04) the model on the other hand is lower than the measurements and the diurnal variation is less pronounced that at the other sites, similar as the general tendency as discussed for the filter measurements (Table 3 and 4).

\section{Conclusion}

EMEP 2006 and 2007 IMPs have produced a set of valuable data which has given new insights and improved our understanding regarding composition of particulate matter in different size fractions, seasonal and geographical differences, gas/aerosol partitioning and diurnal variations. The size segregated and chemically resolved PM measurements and the hourly measurements of gaseous and aerosol species which is not part of the regular EMEP measurement program has led to new possibilities for validation of the EMEP model.

In general, the model has been shown able to reproduce the main features of PM composition, spatial and temporal (summer-winter) variation, though discrepancies between measured and calculated PM have also been found. The availability of PM chemical composition measurements has facilitated a more profound analysis of PM results. Among others, the intensive measurement data has identified improvements needed for increasing the accuracy of the EMEP model aerosol calculations. In particular, size-distribution and formation rates of $\mathrm{HNO}_{3}$ and coarse nitrate. Explicit modelling of the sea-salt and dust reactions will be introduced in future in order to address some of these factors, and more size-resolved measurements of nitrate and other compounds is needed to evaluate such changes properly. Furthermore, the diurnal variation of ammonia would probably improve if the EMEP model is coupled to a dynamic, mechanistic ammonia emission module. The model results for sulphate aerosol have been significantly improved; still its tendency to underestimate sulphate should be further investigated, making also use of hourly measurements. Part of model underestimation of EC, at central and south European sites is probably due to emission uncertainties. Similarly, OC tends to be underestimated at southern sites, suggesting that residential wood burning source is underestimated in winter (Bergström et al., 2012; Denier van der Gon et al., 2012). It should be noted that both primary and secondary OC has been included in the calculations for the first time, showing promising results (Bergström et al., 2012). The lack of measurements of mineral dust hamper the possibility for model evaluation for this highly uncertain PM component, and it is strongly recommended that more sites measure the full set of mineral components (Querol et al., 2011).

It is well known that chemical speciation measurements can be biased, especially for nitrogen and organic species, and the intensive measurements clearly showed that the lack of comparability between datasets makes it difficult for regional assessments and comparison with models. Artefact free methods like continuous measurements and denuders should be applied especially during campaigns like this. It is also apparent that a standardized method is needed to get comparable data for EC and OC, either by using a centralised lab or by agreeing upon a common protocol, even though not perfect. These issues were taken into account during the second intensive measurement period, which was conducted in October 2008 and March 2009. I.e. these periods included centralised laboratories for levoglucosan and ${ }^{14} \mathrm{C}$, and all labs measuring EC/OC followed the same protocol (Yttri et al., 2012; Cavalli et al., 2010).

There are relatively large uncertainties in both measured and modelled estimates, but to quantify this is very difficult. The main reasons for model uncertainty are uncertainties in input data (e.g. emissions, meteorology, landuse, etc.) and uncertainties in processes descriptions in the model. The accuracy of model calculations varies a lot for different PM components, with SIA aerosols being better understood (though still far from being perfectly represented by the model), while SOA and windblown dust being rather uncertain. In the measurements, the uncertainties are both related to measurement method itself and the performance of the analysis. For further details on the uncertainty in assessment 
of PM in Europe the reader is referred to the EMEP PM Status report in 2011 (Tsyro et al., 2011c).

Several of the measurements conducted during the IMPs are relatively new to the EMEP community and there were not established reporting routines for data and metadata, creating challenges regarding reporting of correct units, methodology, correction factors, etc. This new suit of measurements has forced EMEP to develop new reporting guidelines, as well as defining reference methodologies, which was also addressed especially within the EU FP6 infrastructure project EUSAAR (Philippin et al., 2009) and will be followed up in the EU FP7 project ACTRIS (www.actris.net). Further, it is recognized that it is essential to get support from ongoing research projects to coordinate efforts, i.e. with the EU project EUCAARI (Kulmala et al., 2011) which was partner in the follow up intensive periods in 2008 and 2009 (Kulmala et al., 2011; Poulain et al., 2011; Yttri et al., 2012) and ACTRIS for the next intensive periods in 2012 and 2013.

Acknowledgements. This work was supported by EMEP under UNECE. Important updates to the EMEP model were made as part of the EU 6th Framwork programmes EUCAARI (Contract No. 34684) and Nitro-Europe (FP6-2004-No. 017841-2). Several additional people have contributed in the intensive periods, special thanks to Gyula Kiss, Martin Ferm, H. C. Hansson, Christian Plaß-Dülmer, Rami Alfarra, Andres Alastuey, Xavier Querol, Erika Brüggemann, Thomas Gnauk and Hugh Coe. Mark A. Sutton is also greatly acknowledged for being one of the main architects of the concept of EMEP intensive measurement periods (IMP). National or institutional funding has been essential to conduct these intensive periods and this is certainly greatly appreciated. RB's contribution was funded by the Swedish Clean Air Research Programme (SCARP). EN's contribution was funded by the UK Department for Environment, Food and Rural Affairs (Defra). IfT's contribution was supported from the Umweltbundesamt (UBA) research foundation.

Edited by: H. C. Hansson

\section{References}

Aas, W. and Tsyro, S.: Chapter 2.2. Contribution of primary particles, secondary inorganic aerosols (SIA), sea salt and base cations to PM mass. In Transboundary Particulate Matter in Europe: Status Report 2009, Norwegian Institute for Air Research, Kjeller, Norway, EMEP Status Report 4/2011, 2011.

Andersson-Sköld, Y. and Simpson, D.: Comparison of the chemical schemes of the EMEP MSC-W and the IVL photochemical trajectory models, Atmos. Environ., 33, 1111-1129, 1999.

Alastuey, A, Querol, X., Rodríguez, S., Plana F., Lopez-Soler, A., Ruiz, C., and Mantilla. E.: Monitoring of atmospheric particulate matter around sources of secondary inorganic aerosol, Atmos. Environ., 38/30, 4977-4992, 2004.

Bergström, R., Denier van der Gon, H. A. C., Prévôt, A. S. H., Yttri, K. E., and Simpson, D.: Modelling of organic aerosols over Europe (2002-2007) using a volatility basis set (VBS) framework with application of different assumptions regarding the formation of secondary organic aerosol, Atmos. Chem. Phys. Discuss., 12, 5425-5485, doi:10.5194/acpd-12-5425-2012, 2012.

Binkowski, F. S. and Shankar, U.: The regional particulate matter model, 1: model description and preliminary results. J. Geophys. Res., 100, 26191-26209, 1995.

Cavalli, F., Viana, M., Yttri, K. E., Genberg, J., and Putaud, J.-P.: Toward a standardised thermal-optical protocol for measuring atmospheric organic and elemental carbon: the EUSAAR protocol, Atmos. Meas. Tech., 3, 79-89, doi:10.5194/amt-3-79-2010, 2010.

Cavalli, F. and Putaud, J.-P.: Chapter 3. Results of the 2010 intercomparison of TC, OC and EC analytical methods. In: Transboundary Particulate Matter in Europe: Status Report 2009, Norwegian Institute for Air Research, Kjeller, Norway. EMEP Status Report 4/2011, 2011.

CEN: Air quality - Determination of the PM10 fraction of suspended particulate matter. Reference method and field test procedure to demonstrate reference equivalence of measurement methods, EN12341:1999, 1999.

Chan, Y. C., Simpson, R. W., MCtainsh, G. H., Vowles, P. D., Cohen D. D., and Baily, G. M.: Characterisation of chemical species in $\mathrm{PM}_{2.5}$ and $\mathrm{PM}_{10}$ aerosols in Brisbane, Australia. Atmos. Environ., 31, 3773-3785, 1997.

DeCarlo, P. F., Kimmel, J. R., Trimborn, A., Northway, M. J., Jayne, J. T., Aiken, A. C., Gonin, M., Fuhrer, K., Horvath, T., Docherty, K., Worsnop, D. R. and Jimenez, J. L.: Field-Deployable, HighResolution, Time-of-Flight Aerosol Mass Spectrometer. Anal. Chem., 78, 8281-8289, 2006.

Denier van der Gon, H. A. C., Visschedijk, A. Pandis, S. Fountoukis C., Bergström, R. Simpson, D., and Johansson, C.: Particulate emissions from residential wood combustion in Europe - revised estimates and an evaluation, in preparation, 2012.

EMEP: EMEP Manual for sampling and chemical analysis. Norwegian Institute for Air Research, Kjeller, Norway, EMEP/CCCReport 1/1995, last revision in 2001.

EMEP: EMEP particulate matter assessment report. Aas, W., Bruckmann, P., Derwent, D., Poisson, N., Putaud, J.-P., Rouil,. L. Vidic, S., and Yttri, K. E. (Eds): Norwegian Institute for Air Research, Kjeller, Norway. EMEP/CCC-Report 8/2007, 2007.

Fagerli, H. and Aas, W.: Trends of nitrogen in air and precipitation: Model results and observations at EMEP sites in Europe, 1980-2003, Environ. Poll., 154, 448-461, doi:10.1016/j.envpol.2008.01.024, 2008.

Fagerli, H., Gauss, M., Benedictow, A. C., Steensen, B. M., and Hjellbrekke, A.-G.: Acidifying and eutrophying components: validation and combined maps, Supplementary material to EMEP status report 1/2011, available online at www.emep.int, The Norwegian Meteorological Institute, Oslo, Norway, 2011.

Genberg, J., Hyder, M., Stenström, K., Bergström, R., Simpson, D., Fors, E. O., Jönsson, J. Å., and Swietlicki, E.: Source apportionment of carbonaceous aerosol in southern Sweden, Atmos. Chem. Phys., 11, 11387-11400, doi:10.5194/acp-1111387-2011, 2011

Hayman, G., Bergström, R., Jenkin, M. and Simpson, D.: Modelling Photochemical Oxidants in Europe: benchmarking seven chemical mechanisms, in preparation, 2012.

Hauck, H., Berner, A., Gomiscek, B., Stopper, S., Puxbaum, H., Kundi, M., and Preining, O.: On the equivalence of gravimet- 
ric PM data with TEOM and beta-attenuation measurements. J. Aerosol Sci., 35, 1135-1149, 2004.

Jayne, J. T., Leard, D. C., Zhang, X., Davidovits, P., Smith, K. A., Kolb, C. E., and Worsnop, D. R.: Development of an Aerosol Mass Spectrometer for Size and Composition. Analysis of Submicron Particles, Aerosol Sci. Technol., 33, 49-70, 2000.

Kulmala, M., Asmi, A., Lappalainen, H. K., Baltensperger, U., Brenguier, J.-L., Facchini, M. C., Hansson, H.-C., Hov, Ø., O'Dowd, C. D., Pöschl, U., Wiedensohler, A., Boers, R., Boucher, O., de Leeuw, G., Denier van der Gon, H. A. C., Feichter, J., Krejci, R., Laj, P., Lihavainen, H., Lohmann, U., McFiggans, G., Mentel, T., Pilinis, C., Riipinen, I., Schulz, M., Stohl, A., Swietlicki, E., Vignati, E., Alves, C., Amann, M., Ammann, M., Arabas, S., Artaxo, P., Baars, H., Beddows, D. C. S., Bergström, R., Beukes, J. P., Bilde, M., Burkhart, J. F., Canonaco, F., Clegg, S. L., Coe, H., Crumeyrolle, S., D’Anna, B., Decesari, S., Gilardoni, S., Fischer, M., Fjaeraa, A. M., Fountoukis, C., George, C., Gomes, L., Halloran, P., Hamburger, T., Harrison, R. M., Herrmann, H., Hoffmann, T., Hoose, C., Hu, M., Hyvärinen, A., Hõrrak, U., Iinuma, Y., Iversen, T., Josipovic, M., Kanakidou, M., Kiendler-Scharr, A., Kirkevåg, A., Kiss, G., Klimont, Z., Kolmonen, P., Komppula, M., Kristjánsson, J.-E., Laakso, L., Laaksonen, A., Labonnote, L., Lanz, V. A., Lehtinen, K. E. J., Rizzo, L. V., Makkonen, R., Manninen, H. E., McMeeking, G., Merikanto, J., Minikin, A., Mirme, S., Morgan, W. T., Nemitz, E., O’Donnell, D., Panwar, T. S., Pawlowska, H., Petzold, A., Pienaar, J. J., Pio, C., Plass-Duelmer, C., Prévôt, A. S. H., Pryor, S., Reddington, C. L., Roberts, G., Rosenfeld, D., Schwarz, J., Seland, Ø., Sellegri, K., Shen, X. J., Shiraiwa, M., Siebert, H., Sierau, B., Simpson, D., Sun, J. Y., Topping, D., Tunved, P., Vaattovaara, P., Vakkari, V., Veefkind, J. P., Visschedijk, A., Vuollekoski, H., Vuolo, R., Wehner, B., Wildt, J., Woodward, S., Worsnop, D. R., van Zadelhoff, G.-J., Zardini, A. A., Zhang, K., van Zyl, P. G., Kerminen, V.-M., S Carslaw, K., and Pandis, S. N.: General overview: European Integrated project on Aerosol Cloud Climate and Air Quality interactions (EUCAARI) - integrating aerosol research from nano to global scales, Atmos. Chem. Phys., 11, 13061-13143, doi:10.5194/acp11-13061-2011, 2011.

Kupiainen, K. and Klimont, Z.: Primary emissions of fine carbonaceous particles in Europe. Atmos. Environ., 41/10, 2156-2170, doi:10.1016/j.atmosenv.2006.10.066, 2007.

Lanz, V. A., Alfarra, M. R., Baltensperger, U., Buchmann, B., Hueglin, C., and Prévôt, A. S. H.: Source apportionment of submicron organic aerosols at an urban site by factor analytical modelling of aerosol mass spectra, Atmos. Chem. Phys., 7, 15031522, doi:10.5194/acp-7-1503-2007, 2007.

Lanz, V. A., Alfarra, M. R., Baltensperger, U., Buchmann, B., Hueglin, C., Szidat, S., Wehrli, M. N., Wacker, L., Weimer, S., Caseiro, A., Puxbaum, H., and Prévôt, A. S. H.: Source attribution of submicron organic aerosols during wintertime inversions by advanced factor analysis of aerosol mass spectra, Environ. Sci. Technol., 42, 214-220, 2008.

Lanz, V. A., Prévôt, A. S. H., Alfarra, M. R., Weimer, S., Mohr, C., DeCarlo, P. F., Gianini, M. F. D., Hueglin, C., Schneider, J., Favez, O., D'Anna, B., George, C., and Baltensperger, U.: Characterization of aerosol chemical composition with aerosol mass spectrometry in Central Europe: an overview, Atmos. Chem. Phys., 10, 10453-10471, doi:10.5194/acp-10-10453-2010, 2010.
Massad, R.-S., Tuzet A., Loubet B., Perrier A., and Cellier P.: Model of stomatal ammonia compensation point (STAMP) in relation to the plant nitrogen and carbon metabolisms and environmental conditions. Ecological modelling, 221, 479-494, 2010.

McDow, S. R. and Huntzicker, J. J.: Vapor adsorption artifact in the sampling of organic aerosol: face velocity effects, Atmos. Environ., 24A, 2563-2571, 1990.

Nemitz, E., Prévôt, A. S. H., Äijälä, M., Allan, J. D., Baltensperger, U., Berresheim, H., Carbone, S., Canagaratna, M. R., Canonaco, F., Capes, G., Ceburnis, D., Choularton, T., Coe, H., Cubison, M. J., Dall'Osto, M., Di Marco, C. F., DeCarlo, P. F., Ehn, M., Eriksson, A., Freney, E., Herrmann, H., Jimenez, J. L., Hildebrandt, L., Juninen, H., Kiendler-Scharr, A., Laaksonen, A., Lanz, V. A., McFiggans, G., Mensah, A., Mentel, T. F., Mohr, C., O’Dowd, C., Ortega, A., Ovadnevaite, J., Pagels, J., Pandis, S. N., Phillips, G. J., Poulain, L., Raatikainen, T., Saarikoski, S., Sellegri, K., Spindler, G., Sueper, D., Swietlicki, E., Tiitta, P., and Worsnop, D. R.: European submicron aerosol chemical composition derived from a campaign-based Aerosol Mass Spectrometer network, in preparation, 2012.

Pakkanen, T. A., Kerminen, V.-M., Hillamo, R. E., Mäkinen, M., Mäkelä T., and Virkkula, A.: Distribution of nitrate over sea-salt and soil derived particles - Implications from a field study, J. Atmos. Chem. 24, 189-205, 1996.

Pey, J., Pérez, N., Querol, X., Alastuey, A., Cusack, M., and Reche, C.: Intense winter atmospheric pollution episodes affecting the Western Mediterranean. Sci. Total Environ., 408, 1951-1959, 2010.

Philippin, S., Laj, P., Putaud, J.-P., Wiedensohler, A., de Leeuw, G., Fjaeraa, A. M., Platt, U., Baltensperger, U., and Fiebig, M.: EUSAAR - An Unprecedented Network of Aerosol. Observation in Europe, Earozoru Kenkyu, 24, 78-83, 2009.

Pio, C. A. and Lopes, D. A.: Chlorine loss from marine aerosol in a coastal atmosphere. J. Geophys. Res., 103, 25263-25272, 1998.

Poulain, L., Spindler, G., Birmili, W., Plass-Dülmer, C., Wiedensohler, A., and Herrmann, H.: Seasonal and diurnal variations of particulate nitrate and organic matter at the IfT research station Melpitz, Atmos. Chem. Phys., 11, 12579-12599, doi:10.5194/acp-11-12579-2011, 2011.

Putaud, J.-P., Raes, F., Van Dingenen, R. , Brüggemann, E., Facchini, M.-C., Decesari, S., Fuzzi, S., Gehrig, R., Hüglin, C., Laj, P., Lorbeer, G., Maenhaut, W., Mihalopoulos, N., Müller, K., Querol, X., Rodriguez, S., Schneider, J., Spindler, G., Ten Brink, H., Tørseth, K., and Wiedensohler, A.: A European aerosol phenomenology - 2: chemical characteristics of particulate matter at kerbside, urban, rural and background sites in Europe. Atmos. Environ.38, 2579-2595, 2004.

Putaud, J.-P., Van Dingenen, R., Alastuey, A., Bauer, H., Birmili, W., Cyrys, J., Flentje, H., Fuzzi, S., Gehrig, R., Hansson, H.C., Harrison, R.M., Herrmann, H., Hitzenberger, R., Huglin, C., Jones, A.M., Kasper-Giebl, A., Kiss, G., Kousa, A., Kuhlbusch, T.A.J., Loschau, G., Maenhaut, W., Molnar, A., Moreno, T., Pekkanen, J., Perrino, C., Pitz, M., Puxbaum, H., Querol, X., Rodriguez, S., Salma, I., Schwarz, J., Smolik, J., Schneider, J., Spindler, G., ten Brink, H., Tursic, J., Viana, M., Wiedensohler, A., and Raes, F.: A European aerosol phenomenology - 3: Physical and chemical characteristics of particulate matter from 60 rural, urban, and kerbside sites across Europe. Atmos. Environ., 44, 1308-1320, 2010. 
Querol, X., Alastuey, A., Rodriguez, S., Plana, F., Ruiz, C. R., Cots, R., Massagué, G., and Puig. O.: $\mathrm{PM}_{10}$ and $\mathrm{PM}_{2.5}$ source apportionment in the Barcelona Metropolitan area, Catalonia, Spain, Atmos. Environ., 35, 6407-6419, 2001.

Querol, X., Alastuey, A., Pey, J., Cusack, M., Pérez, N., Mihalopoulos, N., Theodosi, C., Gerasopoulos, E., Kubilay, N., and Kocak, M.: Variability in regional background aerosols within the Mediterranean. Atmos. Chem. Phys., 9, 4575-4591, 2009, http://www.atmos-chem-phys.net/9/4575/2009/.

Querol, X., Amato, F., Alastuey, A., Cusack, M., Reche, C., Karanasiou, A. Viana, M., Moreno, T., Pey, J. and Pérez, N.: Atmospheric mineral dust in regional background sites. In Transboundary Particulate Matter in Europe: Status Report 2009, Norwegian Institute for Air Research, Kjeller, Norway, EMEP Status Report 4/2011, 2011.

Renner, E. and Wolke, R.: Simulationen zur Episode hoher Schwebstaubkonzentrationen im Januar und Februar 2006, Immissionsschutz, 2008/1, 13-17, 2006.

Robinson, A. L., Donahue, N. M., Shrivastava, M. K., Weitkamp, E. A., Sage, A. M., Grieshop, A. P., Lane, T. E., Pierce, J. R., and Pandis, S. N.: Rethinking Organic Aerosols: Semivolatile Emissions and Photochemical Aging. Science, 315, 1259-1262, doi:10.1126/science.1133061, 2007.

Schaap, M., Otjes, R. P., and Weijers, E. P.: Illustrating the benefit of using hourly monitoring data on secondary inorganic aerosol and its precursors for model evaluation. Atmos. Chem. Phys., 11, 11041-11053, doi:10.5194/acp-11-11041-2011, 2011

Schmid, H., Laskus, L., Abraham, H. J., Baltensperger, U., Lavanchy, V., Bizjak, M., Burba, P., Cachier, H., Crow, D., Chow, J., Gnauk, Th., Even, A., ten Brink, H. M., Giesen, K.-P., Hitzenberger, R., Hueglin, C., Maenhaut, W., Pio, C., Carvalho, A., Putaud, J.-P., Toom-Sauntry, D. and Puxbaum, H.: Results of the "carbon conference" international aerosol carbon round robin test stage I. Atmos. Environ. 35, 2111-2121, 2001.

Seinfeld, J. H. and Pandis, S. N.: Chapter 9. Thermodynamics of aerosols, in: Atmospheric Chemistry and Physics - From Air Pollution to Climate Change, 2nd Edition, John Wiley \& Sons, New York, 491-543, 2006.

Semb, A., Bartonova, A., Schaug, J., Lükewille, A., and Tørseth, K.: Pilot measurements of nitrogen containing species in air. Norwegian Institute for Air Research, Kjeller, Norway, EMEP/CCC report 5/1998, 1998.

Simpson, D., Yttri, K., Klimont, Z., Kupiainen, K., Caseiro, A., Gelencsér, A., Pio, C., and Legrand, M.: Modeling carbonaceous aerosol over Europe. analysis of the CARBOSOL and EMEP EC/OC campaigns. J. Geophys. Res., 112, D23S14, doi:10.1029/2006JD008158, 2007.

Simpson, D., Benedictow, A., Berge, H., Bergström, R., Emberson, L. D., Fagerli, H., Flechard, C. R., Hayman, G. D., Gauss, M., Jonson, J. E., Jenkin, M. E., Nyíri, A., Richter, C., Semeena, V. S., Tsyro, S., Tuovinen, J.-P., Valdebenito, Á., and Wind, P.: The EMEP MSC-W chemical transport model - technical description, Atmos. Chem. Phys., 12, 7825-7865, doi:10.5194/acp-127825-2012, 2012.

Skjøth, C. A., Geels, C., Berge, H., Gyldenkærne, S., Fagerli, H., Ellermann, T., Frohn, L. M., Christensen, J., Hansen, K. M., Hansen, K. and Hertel, O.: Spatial and temporal variations in ammonia emissions - a freely accessible model code for Europe. Atmos. Chem. Phys., 11, 5221-5236, doi:10.5194/acp-11-5221-
2011, 2011.

Spindler, G., Brüggemann, E., Gnauk, T., Grüner, A., Müller, K., Herrmann, H.: A four-year size-segregated Characterization Study of Particles $\mathrm{PM}_{10}, \mathrm{PM}_{2.5}$ and PM1 depending on Air Mass Origin at Melpitz. Atmos. Environ., 44, 164-173, doi:10.1016/j.atmosenv.2009.10.015, 2010.

Stern, R., Builtjes, P., Schaap, M., Timmermans, R., Vautard, R., Hodzic, A., Memmersheimer, M., Feldmann, H., Renner, E., Wolke, R. and Kerschbaumer, A.: A model inter-comparison study focussing on episodes with elevated PM10 concentrations. Atmos. Environ., 42, 4567-4588, 2008.

Szidat, S., Prévôt, A. S. H., Sandradewi, J., Alfarra, M. R., Synal, H.-A., Wacker, L., and Baltensperger,U.: Dominant impact of residential wood burning on particulate matter in alpine valleys during winter, Geophys. Res. Lett., 34, L05820, doi:10.1029/2006GL028325, 2007.

Thomas, R., Trebs, I., Otjes, R. P., Jongejan, P. A. C., ten Brink, H., Phillips, G., Kortner, M., Meixner, F. X., and Nemitz, E.: An automated analyzer to measure surface-atmosphere exchange fluxes of water-soluble inorganic aerosol compounds and reactive trace gases. Environ. Sci. Technol., 43, 1412-1418, doi:10.1021/es8019403, 2009.

Tsyro, S. G.: To what extent can aerosol water explain the discrepancy between model calculated and gravimetric $\mathrm{PM}_{10}$ and $\mathrm{PM}_{2.5}$ ?, Atmos. Chem. Phys., 5, 515-532, doi:10.5194/acp-5515-2005, 2005.

Tsyro, S., Simpson, D., Tarrason, L., Klimont, Z., Kupiainen, K., Pio, C., and Yttri, K. E.: Modelling of elemental carbon over Europe, J. Geophys. Res., 112, D23S19, doi:10.1029/2006JD008164, 2007.

Tsyro, S., Yttri, K. E., and Aas, W.: Chapter 2.1 PM mass concentrations. In Transboundary Particulate Matter in Europe: Status Report 2009, Norwegian Institute for Air Research, Kjeller, Norway, EMEP Status Report 4/2011, 2011 a.

Tsyro, S., Aas, W., Soares, J., Sofiev, M., Berge, H., and Spindler, G.: Modelling of sea salt concentrations over Europe: key uncertainties and comparison with observations. Atmos. Chem. Phys. 11, 10367-10388, doi:10.5194/acp-11-10367-2011, 2011b.

Tsyro, S., Aas, W., Yttri, K. E., and Schultz, M.: Chapter 7. Main uncertainties in the assessment of transboundary PM. In Transboundary Particulate Matter in Europe: Status Report 2009, Norwegian Institute for Air Research, Kjeller, Norway, EMEP Status Report 4/2011, 2011c.

Tørseth, K., Aas, W., Breivik, K., Fjæraa, A. M., Fiebig, M., Hjellbrekke, A. G., Lund Myhre, C., Solberg, S., and Yttri, K. E.: Introduction to the European Monitoring and Evaluation Programme (EMEP) and observed atmospheric composition change during 1972-2009, Atmos. Chem. Phys., 12, 5447-5481, doi:10.5194/acp-12-5447-2012, 2012.

UNECE: The EMEP Monitoring Strategy and measurement programme 2004-2009, EB.AIR/GE.1/2004/5, available at: http: //www.unece.org/env/lrtap/emep/MonitoringStrategy_full.pdf , 2004.

UNECE: Progress report prepared by the Co-Chairs of the Task Force on Measurements and Modelling in collaboration with the secretariat. Paragraph 10 and 11, EB.AIR/GE.1/2005/3, available at: http://www.unece.org/env/documents/2005/eb/ge1/ eb.air.ge.1.2005.3.e.pdf, 2005. 
UNECE: The EMEP Monitoring Strategy and measurement programme 2010-2019, ECE/EB.AIR/GE.1/2009/15, available at: http://www.unece.org/env/documents/2009/EB/ge1/ece.eb. air.ge.1.2009.15.e.pdf, 2009.

Wiedinmyer, C., Akagi, S. K., Yokelson, R. J., Emmons, L. K., AlSaadi, J. A., Orlando, J. J., and Soja, A. J.: The Fire INventory from NCAR (FINN): a high resolution global model to estimate the emissions from open burning, Geosci. Model Dev., 4, 625641, doi:10.5194/gmd-4-625-2011, 2011.

Yttri, K. E., Aas, W., Bjerke, A., Cape, J. N., Cavalli, F., Ceburnis, D., Dye, C., Emblico, L., Facchini, M. C., Forster, C., Hanssen, J. E., Hansson, H. C., Jennings, S. G., Maenhaut, W., Putaud, J. P., and Tørseth, K.: Elemental and organic carbon in $\mathrm{PM}_{10}$ : a one year measurement campaign within the European Monitoring and Evaluation Programme EMEP, Atmos. Chem. Phys., 7, 5711-5725, doi:10.5194/acp-7-5711-2007, 2007.
Yttri, K. E., Simpson, D., Nøjgaard, J. K., Kristensen, K., Genberg, J., Stenström, K., Swietlicki, E., Hillamo, R., Aurela, M., Bauer, H., Offenberg, J. H., Jaoui, M., Dye, C., Eckhardt, S., Burkhart, J. F., Stohl, A., and Glasius, M.: Source apportionment of the summer time carbonaceous aerosol at Nordic rural background sites, Atmos. Chem. Phys., 11, 13339-13357, doi:10.5194/acp11-13339-2011, 2011.

Yttri, K. E., Simpson, D., Prevot, A., Szidat, S., Ceburnis, D., Hueglin, C., Kiss, G., Noeygaard, J. K., Putaud, J.-P., Spindler, G., Vana, M., Perrino, C., and Aas, W.: Source apportionment of the carbonaceous aerosol at European rural background sites, in preparation, 2012. 